\title{
The canopy interception-landslide initiation conundrum: insight from a tropical secondary forest in northern Thailand
}

\author{
Roy C. Sidle ${ }^{1}$ and Alan D. Ziegler ${ }^{2}$ \\ ${ }^{1}$ Sustainability Research Centre, University of the Sunshine Coast, 90 Sippy Downs Drive, \\ Sippy Downs, Queensland 4556, Australia \\ ${ }^{2}$ Department of Geography, National University of Singapore, AS2, \#03-01, 1 Arts Link, \\ Kent Vale, 117570, Singapore \\ Correspondence to: Roy C. Sidle (rsidle@usc.edu.au)
}

Received: 26 February 2016 - Published in Hydrol. Earth Syst. Sci. Discuss.: 9 May 2016 Revised: 20 December 2016 - Accepted: 5 January 2017 - Published: 31 January 2017

\begin{abstract}
The interception and smoothing effect of forest canopies on pulses of incident rainfall and its delivery to the soil has been suggested as a factor in moderating peak pore water pressure in soil mantles, thus reducing the risk of shallow landslides. Here we provide 3 years of rainfall and throughfall data in a tropical secondary dipterocarp forest characterized by few large trees in northern Thailand, along with selected soil moisture dynamics, to address this issue. Throughfall was an estimated $88 \%$ of rainfall, varying from 86 to $90 \%$ in individual years. Data from 167 events demonstrate that canopy interception was only weakly associated (via a nonlinear relationship) with total event rainfall, but not significantly correlated with duration, mean intensity, or antecedent 2-day precipitation $\left(\mathrm{API}_{2}\right)$. Mean interception during small events $(\leq 35 \mathrm{~mm})$ was $17 \%$ ( $n=135$ events) compared with only $7 \%$ for large events ( $>35 \mathrm{~mm} ; n=32)$. Examining small temporal intervals within the largest and highest intensity events that would potentially trigger landslides revealed complex patterns of interception. The tropical forest canopy had little smoothing effect on incident rainfall during the largest events. During events with high peak intensities, high wind speeds, and/or moderate-to-high pre-event wetting, measured throughfall was occasionally higher than rainfall during large event peaks, demonstrating limited buffering. However, in events with little wetting and low-to-moderate wind speed, early event rainfall peaks were buffered by the canopy. As rainfall continued during most large events, there was little difference between rainfall and throughfall depths. A comparison of both rainfall and throughfall depths to conservative mean intensity-duration
\end{abstract}

thresholds for landslide initiation revealed that throughfall exceeded the threshold in $75 \%$ of the events in which rainfall exceeded the threshold for both wet and dry conditions. Throughfall intensity for the 11 largest events (rainfall $=65$ $116 \mathrm{~mm}$ ) plotted near or above the intensity-duration threshold for landslide initiation during wet conditions; 5 of the events were near or above the threshold for dry conditions. Soil moisture responses during large events were heavily and progressively buffered at depths of 1 to $2 \mathrm{~m}$, indicating that the timescale of any short-term smoothing of peak rainfall inputs (i.e., $\leq 1 \mathrm{~h}$ ) has little influence on peak pore water pressure at depths where landslides would initiate in this area. Given these findings, we conclude that canopy interception would have little effect on mitigating shallow landslide initiation during the types of monsoon rainfall conditions in this and similar tropical secondary forest sites.

\section{Introduction}

Mechanisms of slope failure in relatively shallow soil mantles during rain events are generally well understood. Typically, a positive pore water pressure develops just above a hydrologic discontinuity in the regolith, causing an abrupt decline in shear strength and resultant rapid landslide ( $\mathrm{Si}-$ dle and Swanston, 1982; Harp et al., 1990; Fernandes et al., 1994; Kuriakose et al., 2008; Sidle and Bogaard, 2016). Alternatively, landslides have been known to occur due to an increase in soil weight and a reduction in soil suction as soils wet during events (Sasaki et al., 2000; Lacerda, 2007; Godt 
et al., 2009; Yamao et al., 2016). In contrast, some interactions amongst vegetation, site hydrology, and slope stability are not as well understood. In particular, the role of canopy interception of precipitation has drawn considerable speculation with little supporting field data.

Reinforcement of potentially unstable slopes by root systems of woody vegetation is well recognized (Gray and Megahan, 1981; Schmidt et al., 2001; Roering et al., 2003; Stokes et al., 2009; Schwartz et al., 2012), as is the effect of vegetation management on root strength (Ziemer, 1981; Sidle and $\mathrm{Wu}, 1999$; Sidle et al., 2006; Imaizumi et al., 2008; DeGraff et al., 2012; Schwartz et al., 2013). In contrast to this mechanical reinforcement of shallow soil mantles by roots, the effects of the presence or absence of trees on transpiration, interception, water redistribution, and subsequent pore pressure formation in the subsurface remain a topic of controversy, especially when related to shallow landslide initiation (Keim and Skaugset, 2003; Reid and Lewis, 2009; Ghestem et al., 2011; Greco et al., 2013; Dhakal and Sullivan, 2014).

Deep-rooted woody vegetation extracts soil water near potential failure planes during periods of high transpiration; however, such effects typically are not expected to augment slope stability during extended rainy periods when soils are already at field capacity, especially in temperate regions (Megahan, 1983; Sidle and Ochiai, 2006). In the tropics, where evapotranspiration rates are sustained year-round, the potential for modification of the soil moisture regime when trees are removed may be greater. Nevertheless, simulations of soil moisture in a Peninsular Malaysian rain forest indicate that evapotranspiration more significantly affects soil moisture during events preceded by dry conditions than events preceded by wet conditions; it is during these wet periods that shallow landslides are more likely to occur (Sidle, 2005; Sidle et al., 2006).

Because forests intercept and evaporate rainwater back to the atmosphere, less rainfall typically reaches the forest floor when canopies are intact (Rowe et al., 1999; Crockford and Richardson, 2000; Reid and Lewis, 2009; Ziegler et al., 2009; Kato et al., 2013). However, the effects of canopy interception are affected by antecedent precipitation, wind, rainfall intensity and duration, and canopy structure (Xiao et al., 2000; Scott et al., 2003; Pypker et al., 2005; Germer et al., 2006; Kato et al., 2013). As such, canopy interception can vary greatly from event to event at a given site (Keim et al., 2004; Ziegler et al., 2009). Most studies show that the percentage of rainfall intercepted by tree canopies is most variable and highest for small events compared to larger events (Filoso et al., 1999; Keim et al., 2004; Germer et al., 2006; Reid and Lewis, 2009; Ziegler et al., 2009; Dhakal and Sullivan, 2014). In addition to interception of rainwater, forest canopies have been reported to exert a buffering effect on short-term pulses of incident rainfall (Xiao et al., 2000; Keim and Skaugset, 2003; Keim et al., 2006). Using a stochastic representation of rainfall, canopy evaporation, and rainfall transfer through the canopy, Keim et al. (2004) showed that effective rain intensity during large events was reduced more for short-duration events than for long-duration events; during small events, such differences with storm duration were not apparent.

Based on reports of interception and intensity smoothing in forest canopies, it has been advocated that canopy removal could lead to more intense pulses of rainfall infiltrating into forest soils and subsequently higher pore water pressures in the subsurface that could exacerbate landsliding (Rowe et al., 1999; Keim and Skaugset, 2003; Keim et al., 2004; Reid and Lewis, 2007, 2009). If this is true, then in addition to the delayed effect of root decline after tree removal, there could also be an immediate negative effect due to the lack of canopy interception and subsequent potential to increase pore water pressure. While attempts have been made to include canopy interception losses into subsurface hydrology (Keim et al., 2006) and landslide models (Wilkinson et al., 2002), it is not clear what the mechanistic effects are on slope stability. Most canopy interception studies have been conducted in temperate forests, but this information is especially needed in tropical rain forests to assess the possible effects of canopy removal on landslide initiation in these regions where management pressures are rapidly increasing.

One major issue related to slope stability is to determine whether canopy interception significantly reduces incident rainfall with respect to established conservative rainfall intensity-duration thresholds for landslide initiation. Another issue relates to finding evidence that canopy interception significantly affects event soil moisture dynamics to an extent that it would influence shallow landslide initiation. These issues were addressed within the context of a 3-year field investigation in a disturbed, secondary hill dipterocarp forest stand in northern Thailand. The research objectives were to (1) evaluate rainfall interception by a secondary tropical forest canopy for a large number of monsoon events, (2) compare throughfall and rainfall rates to intensity-duration threshold relationships established for shallow landslides, and (3) determine the effect of canopy interception on the potential for soil water increases that could trigger landslides.

\section{Site description}

The Mae Sa experimental catchment (Mae means "river" in the Thai language), a headwater catchment of the Ping River, is located northwest of Chiang Mai in northern Thailand $\left(18^{\circ} 54^{\prime} 06.8^{\prime \prime} \mathrm{N}, 98^{\circ} 53^{\prime} 14.2^{\prime \prime} \mathrm{E}\right.$; Fig. 1a). The $74.2 \mathrm{~km}^{2}$ catchment is mountainous, with elevations ranging from 500 to $1400 \mathrm{~m}$ a.s.l. The topography is characterized by steep slopes (some exceeding $45^{\circ}$ ) and narrow valleys. The geology of the catchment includes granites and gneiss, with some marble and limestone. Soils include Ultisols, Alfisols, and Inceptisols; soil depth typically exceeds $2 \mathrm{~m}$. Land cover is pri- 
marily mixed secondary forests and scrublands (together approximately $80 \%$ of the land area), with ongoing conversion to floriculture, greenhouse operations, and intensive agriculture, especially tree crops (Fig. 1b). These agricultural activities, in addition to ecotourism, support the economies of several small villages. Much of the development, including the building and maintenance of major roads, is located immediately adjacent to the Sa River and its tributaries. A few recent landslides have occurred within the upper catchment (personal observations); most are triggered by runoff, either from compacted road surfaces or intercepted subsurface flow along cut slopes, that is discharged onto fill slopes or unstable slopes below the road (Sidle et al., 2006). Given the rapid revegetation of these tropical sites, it is difficult to detect older landslides.

The catchment is the site of ongoing investigations of hydrological and land-use change (Sidle and Ziegler, 2010; Bannwarth et al., 2014a, b; Ziegler et al., 2014a, b). Associated instrumentation includes 11 spatially distributed rain gauges and one stream gauging station that monitors discharge and turbidity at the mouth of the catchment on a subhourly timescale (Fig. 1). Mean annual rainfall in the catchment varies from 1500 to $2000 \mathrm{~mm} \mathrm{yr}^{-1}$. Approximately $22 \%$ of the annual precipitation is delivered as intense rainfall ( $>20 \mathrm{~mm} \mathrm{~h}^{-1}$ based on $1 \mathrm{~min}$ recorded intensities) during the monsoon season between May and November. The catchment has a mean annual runoff ratio of approximately $30 \%$ (Ziegler et al., 2014b).

The throughfall experiment was conducted at station 429 (Fig. 1b), which consists of a hydrometeorological tower that measures water and energy fluxes within an upland, dipterocarp forest. Trees are typically 10 to $16 \mathrm{~m}$ tall in the forest; tree trunk diameter ranges from 2 to $77 \mathrm{~cm}$. Tree density in the plot is moderate: 127 trees within a $350 \mathrm{~m}^{2}$ plot. Leaf area index (LAI) ranges from 1.8 to 3.2 , as determined at 117 point locations using fisheye digital photographs and Delta-T HemiView software (www.delta-t.co.uk). The forest is secondary (ca 20-30 years since partial clearance) and is typically burned annually, but fire only affects the understory vegetation.

A total of 34 tree species are found in the plot, along with 3 types of bamboo: Bambusa tulda Roxb. (Poaceae), Bambusa pallida (Poaceae), and Dendrocalamus nudus Pilg. (Poaceae). Dominant tree species are Shorea obtusa Wall. Ex Bl. (Dipterocarpaceae) and Quercus kerrii Craib var. kerrii (Fagaceae). Other important species include: Lithocarpus polystachyus (Wall. Ex A. DC.) Rehder. (Fagaceae); Tectona grandis L. f. (Verbenaceae); Craibiodendron stellatum (Pierre) W.W. Sm. (Ericaceae); Cratoxylum formosum (Jack) Dyer ssp. Pruniflorum (Kurz) Gogel. (Guttiferae, Hypericeae); Dipterocarpus tuberculatus Roxb. var. tuberculatus (Dipterocarpaceae); Gardenia sootepensis Hutch. (Rubiaceae); Pterocarpus marocarpus Kurz. (Leguminosae, Papilionoideae); Shorea siamensis Miq. var. siamensis (Dipte-
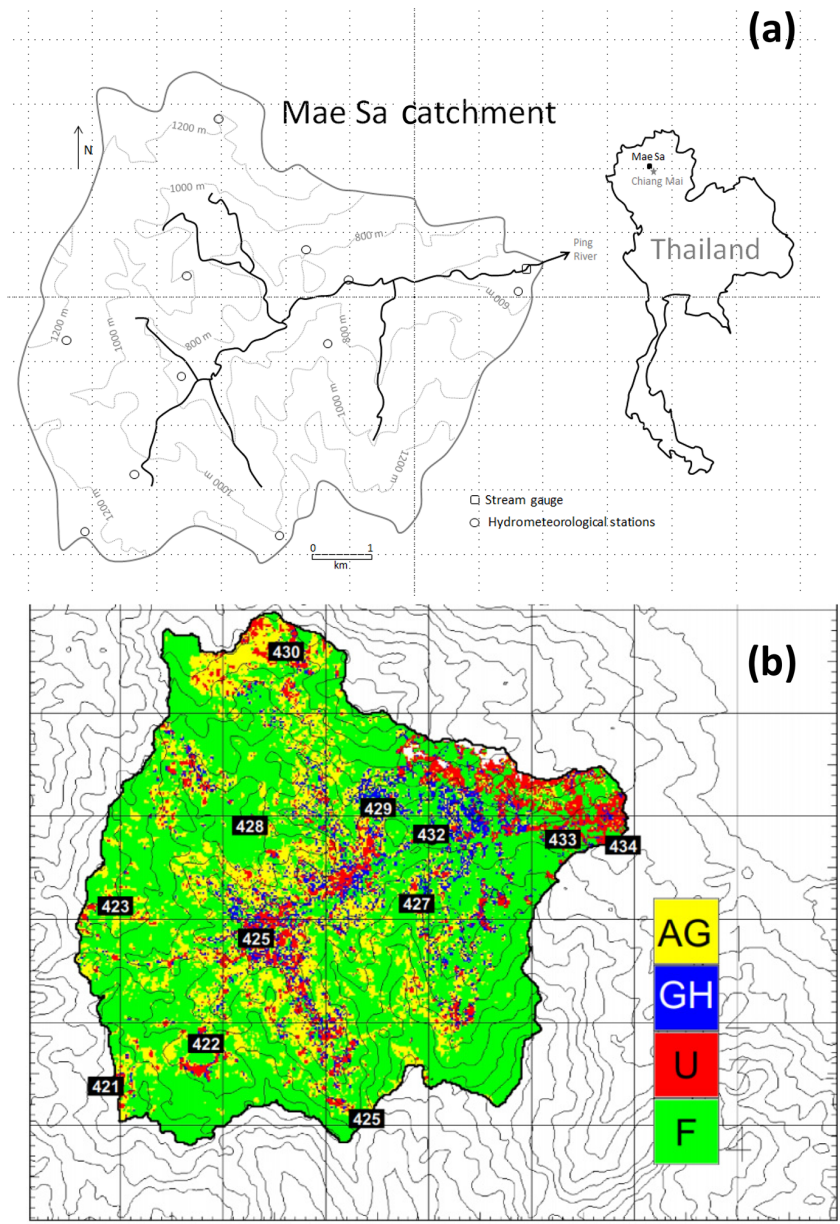

Figure 1. Site map of the Mae Sa experiment site in northern Thailand. Panel (a) shows the catchment location in Thailand, the topography, and major stream channels. Panel (b) shows major land covers in the Mae Sa catchment, including hillslope and plantation agriculture (AG, $23 \%$ ), greenhouse agriculture $(\mathrm{GH}, 7 \%)$, urbanized or peri-urban areas (U, $8 \%$ ), and forest cover with various degrees of disturbance (F, 62\%). Grid cell dimensions are $2 \mathrm{~km} \times 2 \mathrm{~km}$. Rectangles demarcate hydrometeorological measurement sites. Streamflow, total suspended solids, particulate organic carbon, and particulate organic nitrogen were measured at the stream gauge station 434 . Rainfall is measured at all other numbered hydrometeorological stations (rectangles). The throughfall investigation reported in this paper was conducted at station 429 , where rainfall, throughfall, and soil moisture were monitored.

rocarpaceae); and Wendlandia tinctoria (Roxb.) DC. subsp. Orientalis Cowan (Rubiaceae).

The soil at the site is an Ultisol with a thin $(<20 \mathrm{~cm})$ brown A horizon underlain by a dark red $B$ horizon that extends below a depth of $2 \mathrm{~m}$. Saturated hydraulic conductivity declines exponentially from the surface $\left(\sim 136 \mathrm{~mm} \mathrm{~h}^{-1}\right)$ to approximately $<4 \mathrm{~mm} \mathrm{~h}^{-1}$ at a depth of $25 \mathrm{~cm}$; values at 1 and $2 \mathrm{~m}$ are 1 to $2 \mathrm{~mm} \mathrm{~h}^{-1}$ ( $n=3$ measurements for all depths; unpublished data, determined with a borehole permeameter). 
The decrease in saturated hydraulic conductivity is typical of that in other profiles found in southeast Asia (cf. Ziegler et al., 2004, 2006). Macropores and fissures, features that could influence preferential flow through the soil, were not abundant in the subsoil. Bulk density does not change much over this depth range $\left(1.08,1.26\right.$, and $1.38 \mathrm{~g} \mathrm{~cm}^{-3}$ for the surface and depths of 1 and $2 \mathrm{~m}$, respectively). Corresponding porosity for the three depths is $0.59,0.52$, and 0.48 (based on a particle density of $2.65 \mathrm{~g} \mathrm{~cm}^{-3}$ ).

\section{Methods}

\subsection{Measurements}

A tipping-bucket rain gauge was mounted on a meteorological tower at a height of $18 \mathrm{~m}$, about $1 \mathrm{~m}$ above the tallest canopy trees $(820 \mathrm{~m}$ a.s.l.) to measure incident rainfall (station 429, Fig. 1b). For our analyses, we examined all events that occurred from 6 May 2005 to 21 November 2007. To be considered an event, total rainfall during a period had to be $\geq 8 \mathrm{~mm}$, with no precipitation break $>4 \mathrm{~h}$. We included a range of monsoon storms to assess interception losses for potential landslide-triggering events and those that were smaller.

Throughfall was collected in a system consisting of six $4 \mathrm{~m}$ long gutters radiating from a central tipping-bucket device that was installed under the canopy and secured at heights of 0.5 to $1.0 \mathrm{~m}$ above the ground at a slight angle $\left(\leq 6^{\circ}\right)$ to promote rapid drainage (Fig. 2a); the angle was based on prior experience (Ziegler et al., 2009). Each collection gutter of the throughfall system was $43.5 \mathrm{~mm}$ wide, with a triangularshaped channel and $25 \mathrm{~mm}$ vertical risers to reduce rain splash loss. All gutters drained into a large tipping-bucket to measure real-time throughfall response for comparison with incident rainfall. The volume of throughfall required to produce one tip was 230 to $240 \mathrm{~cm}^{3}(0.22$ to $0.23 \mathrm{~mm})$. A dynamic calibration correction was applied to account for differences in tip volume over the range of observed tipping rates (Calder and Kidd, 1978; Marsalek, 1981; Humphrey et al., 1997; Ziegler et al., 2009). These differences are caused by losses that occur as the tipping mechanism moves while rainfall drains from the funnel. This relationship was determined by draining known volumes of water through the tipping-bucket system $\left(\mathrm{mm} \mathrm{tip}^{-1}\right)$ and recording the number of tips registered.

The volume of rainfall within a given time interval was divided by the total surface collection area of the entire gutter system, corrected for the angle of inclination $\left(\right.$ area $\left.=1.044 \mathrm{~m}^{2}\right)$, to calculate total throughfall for the interval. A correction was also applied to account for splash error occurring during high-intensity throughfall. Based on data collected from seven events using a paired tipping-bucket rain gauge and a throughfall system installed in an open area (i.e., both were used to measure rainfall), we observed that
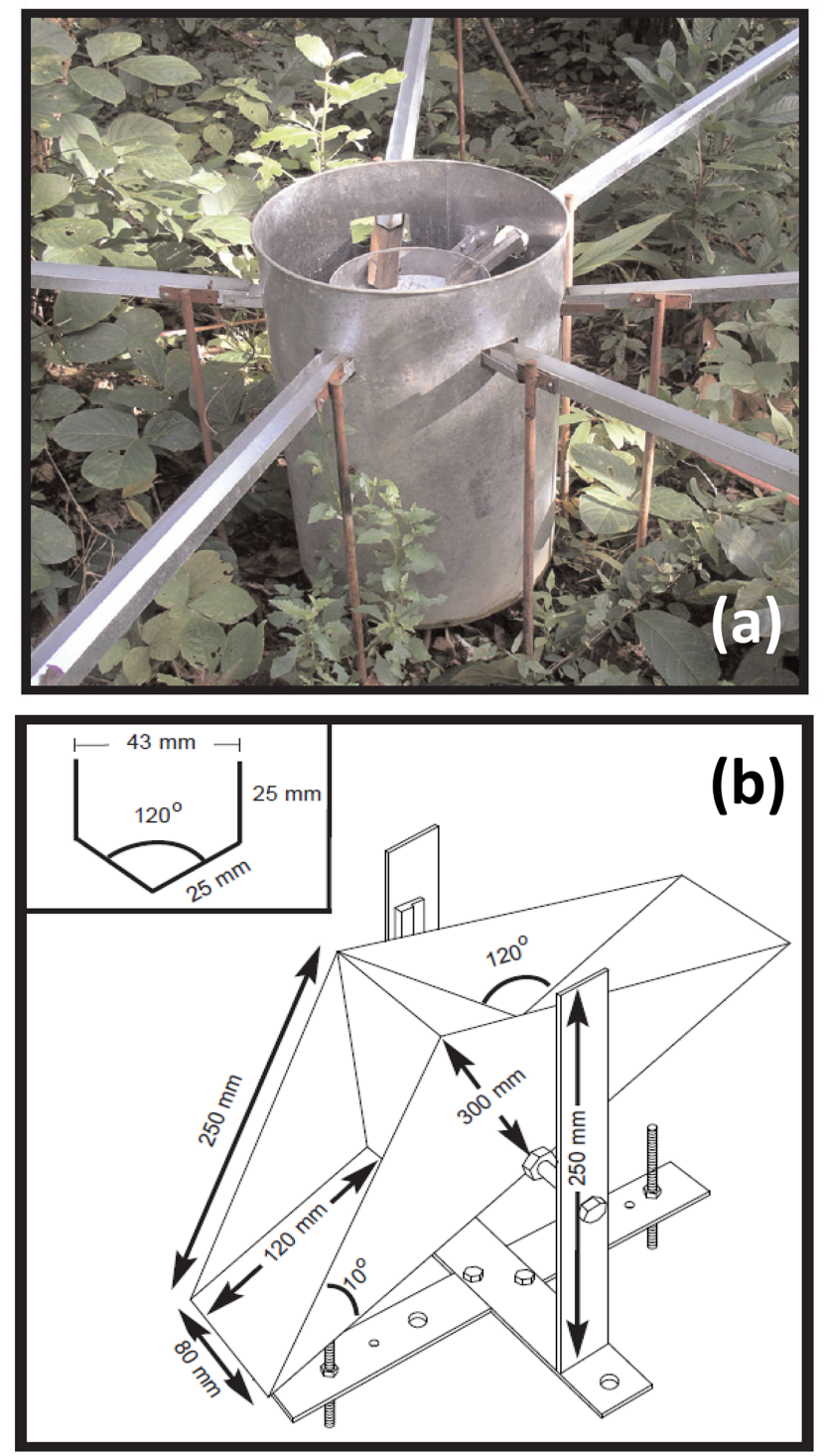

Figure 2. (a) Stationary collector with six collection troughs (gutters). (b) Schematic of stationary gauge tipping-bucket mechanism (located inside the collector base); the inset shows the dimensions for the collection troughs (gutters).

substantial splash loss occurred during high-intensity events. Total event rainfall depths between the devices could be achieved when calibrated tip volumes were increased 50 to $78 \%$ (via linear regression) during high-intensity periods of events (i.e., for rates of 5 to 12 tips per minute). We used this relationship to adjust the rates for high-intensity throughfall measured in this study.

We recognize several limitations in this correction: (1) the correction is based on limited data (unpublished); (2) some splash error probably also occurred at lower intensities ( $<5$ tips per minute), but the data set does not allow us to quantify it; and (3) the splash error associated with open rain- 
fall may not be the same as that for throughfall, owing to different drop sizes and drop direction (both of which vary from event to event). Nevertheless, after applying this crude correction, the total event throughfall depths were within the ranges (relative to rainfall) expected for the events measured (i.e., the $C_{\mathrm{i}}$ of increasingly large events approached a value of 0 ; see Fig. 3a). Thus, we believe any residual errors due to splash (after correction) are minor; importantly, these errors would not change our final interpretations.

The time interval used to assess both rainfall and throughfall inputs via the respective tipping-bucket devices was $1 \mathrm{~min}$. Although the collector was kept in the same location during the 3-year study, gutters have an advantage over using conventional, movable, tipping-bucket rain gauges because they integrate throughfall under much of the variable canopy structure (Ziegler et al., 2009). Spatial integration of throughfall is especially important in tropical forests where multitiered canopies create considerable variability in throughfall (Lloyd and Marques, 1988; Dykes, 1997; Konishi et al., 2006).

Soil moisture was monitored at the soil surface and depths of 1 and $2 \mathrm{~m}$ in the same forest patch using Campbell Scientific (Logan, UT, USA) CS615 soil moisture probes, connected to a Campbell CR23X datalogger. The probes were situated less than $10 \mathrm{~m}$ from the throughfall collection system under the forest canopy. Soil moisture measurements were recorded at $20 \mathrm{~min}$ intervals (note: these are instantaneous measurements, not means). Values recorded with the CS615 were converted to volumetric water contents via sensor-specific calibration curves determined from manual samples collected within the soil profile at the time of installation and during subsequent periods of both wet and dry seasons. During the latter periods, manual samples were collected by augering holes to a depth of $2 \mathrm{~m}$ near the probe site. Volumetric samples were collected with an AMS (American Falls, ID, USA) bulk density sampler. The calibration curve was determined via linear regression from the reflectometer (independent variable) and paired volumetric water content (dependent variable) data. Details of this calculation are provided by the manufacturer (https://s.campbellsci.com/ documents/us/manuals/cs616.pdf).

\subsection{Calculations}

Canopy interception ratio $\left(C_{\mathrm{i}}\right)$ is calculated as

$C_{\mathrm{i}}=(\mathrm{RF}-\mathrm{TH}) \mathrm{RF}^{-1}$,

where RF is the incident rainfall during an event or a portion of the event ( $\mathrm{mm})$ and $\mathrm{TH}$ is the throughfall $(\mathrm{mm})$ during the same period of time. Values of $C_{\mathrm{i}}$ approaching 0 indicate no canopy interception for that event or period of the event.

To create a conservative predictor of shallow landslides, a number of regional studies have generated the lowest thresholds for slope failure based on average rainfall intensity-duration relationships (Larsen and Simon, 1993;
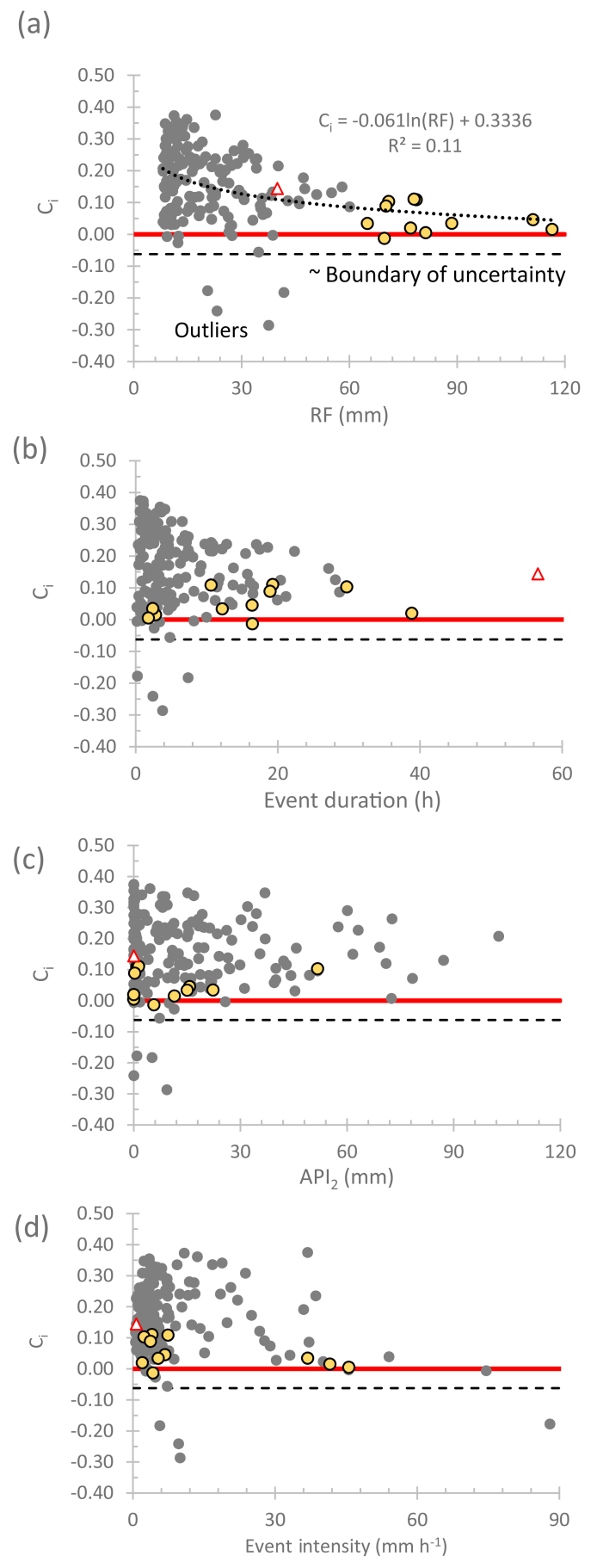

Figure 3. (a) Canopy interception ratio $\left(C_{\mathrm{i}}\right)$ versus total event rainfall for all monitored events. The nonlinear regression curve describes the tendency for $C_{\mathrm{i}}$ to approach 0 as total rainfall increases. (b) $C_{\mathrm{i}}$ plotted with respect to event duration (h). (c) $C_{\mathrm{i}}$ plotted against 2-day antecedent precipitation $\left(\mathrm{API}_{2}\right)$. (d) $C_{\mathrm{i}}$ plotted with respect to mean event intensity $\left(\mathrm{mm} \mathrm{h}^{-1}\right)$. The open circles and the triangle in all panels refer to the 11 large and 1 long storm investigated in detail (Table 2). The four events plotted below the dashed line are considered outliers. 
Aleotti, 2004; Guzzetti et al., 2008; Dahal and Hasegawa, 2008) based on an earlier global concept developed by Caine (1980). Sidle and Ochiai (2006) modified Caine's global intensity-duration threshold by removing some very short and very long ( $>10$ days) events that misrepresented rainfall-landslide initiation data. The resulting relationship is given as

$I=13.58 D^{-0.38}$,

where $I$ is the mean event intensity $\left(\mathrm{mm} \mathrm{h}^{-1}\right)$ and $D$ is the duration of the event (h). To assess the effects of antecedent rainfall on the intensity-duration relationship, all of Caine's (1980) data that included 2-day antecedent rainfall $\left(\mathrm{API}_{2}\right)$ together with new data were plotted separately for $\mathrm{API}_{2} \leq 20 \mathrm{~mm}$ and $\mathrm{API}_{2}>20 \mathrm{~mm}$ (Sidle and Ochiai, 2006). Two-day antecedent rainfall was used because this parameter correlated well with maximum piezometric response in unstable hollows (Sidle, 1992). The intensity-duration relationship developed for the events preceded by dry $(\leq 20 \mathrm{~mm})$ antecedent conditions is the following (Sidle and Ochiai, 2006):

$I=19.99 D^{-0.38}$,

where $I$ and $D$ are as in Eq. (2). For the events preceded by wet antecedent conditions, the following relationship is used:

$I=12.64 D^{-0.49}$,

where $I$ and $D$ are as above. The global modified Caine threshold (Eq. 2) is lower than the dry condition threshold (Eq. 3) for all combinations of event intensity-duration. Furthermore, because the equations are based on duration, the modified Caine threshold is higher than the wet condition threshold (Eq. 4) for events exceeding $1 \mathrm{~h}$. It should be noted that storms that exceed any of these thresholds will not necessarily trigger a landslide; rather, it means that the very minimum rainfall conditions (i.e., average intensity and duration) for global landslides have been met. Herein we employ these thresholds to ascertain whether interception has a significant effect on the intensity-duration relations that may trigger landslides at our site.

\section{Results}

\subsection{Canopy interception for all events}

The maximum, minimum, and mean rainfall totals for the 167 recorded events during the 3-year study were 116.4, 8.1 , and $24.3 \mathrm{~mm}$, respectively. The corresponding totals for throughfall were 114.6, 5.7, and $21.3 \mathrm{~mm}$, respectively. Event mean rainfall intensity (depth/duration) ranged from 0.5 to $88.0 \mathrm{~mm} \mathrm{~h}^{-1}$. The mean event intensity of all 167 events was $9.1 \mathrm{~mm} \mathrm{~h}^{-1}$. The duration of the 167 events ranged from about 9 min to $57 \mathrm{~h}$, with a mean duration of about $7 \mathrm{~h}$.
Table 1. Number of events sampled each year and corresponding rainfall and throughfall totals.

\begin{tabular}{lrrrrr}
\hline Year & Events & $\begin{array}{r}\text { Mean depth } \\
(\mathrm{mm})\end{array}$ & $\begin{array}{r}\text { Rainfall } \\
(\mathrm{mm})\end{array}$ & $\begin{array}{r}\text { Throughfall } \\
(\mathrm{mm})\end{array}$ & $\begin{array}{r}\text { Throughfall } \\
(-)\end{array}$ \\
\hline 2005 & 52 & 22 & 1149 & 1037 & 0.90 \\
2006 & 59 & 28 & 1678 & 1450 & 0.86 \\
2007 & 56 & 22 & 1235 & 1078 & 0.87 \\
Total & 167 & 24 & 4062 & 3564 & 0.88 \\
\hline
\end{tabular}

Mean depth refers to the mean rainfall depth of the 52,58 , or 56 events in a given year (2005, $2006,2007)$. Throughfall is listed as both a depth and a fraction of total rainfall.

A total of 52,59, and 56 events were monitored in 2005, 2006, and 2007 (Table 1). Mean event size ranged from 22 to $28 \mathrm{~mm}$. Rainfall depths for the 3 years varied from 1149 to $1678 \mathrm{~mm}$; the corresponding throughfall depth range was 1037 to $1450 \mathrm{~mm}$ (Table 1). Annual estimates of throughfall (fraction of rainfall) were $0.90,0.86$, and 0.87 . We can only speculate that annual variations result from minor changes in canopy characteristics (based on observations) and differences in event rainfall characteristics. Further, we believe the inherent error in the calculation of throughfall for any one event is on the order of $\pm 6 \%$. The differences in the yearly calculations are within this tolerance.

The 3-year throughfall fraction estimate was 0.88 , which is near the higher end of values reported for forests in southeast Asia (Sinun et al., 1992; Dykes, 1997; Konishi et al., 2006; Ziegler et al., 2009; Tanaka et al., 2015). The throughfall estimate may be slightly elevated for the following reasons: (a) the stand was a recovering secondary forest (i.e., lacking a multistory canopy) with low LAI (1.8 to 3.2); (b) the eventbased estimate does not include many very small events when canopy interception is expected to be high (i.e., we only report throughfall for events representing 78,87 , and $82 \%$ of incident rainfall entering the forest in 2005, 2006, and 2007; data not shown); (c) undercatch of rainfall above the canopy during windy conditions; and (d) throughfall measurement errors or uncertainty. Nevertheless, we believe the method provided reasonably accurate data for this type of analysis.

For the 167 events, throughfall ranged widely from 62 to $129 \%$ of rainfall (Fig. 4). When expressed as a canopy interception ratio $\left(C_{\mathrm{i}}\right.$, Eq. 1), values ranged from -0.29 to 0.38 , with the mean for all 167 events being 0.15 (Fig. 3). Throughfall was greater than incident rainfall during nine events (Fig. 3b), but only for four events was the difference greater than $6 \%$, a value we consider to be approximately the uncertainty in the throughfall estimate. Most of the events where throughfall was greater than rainfall occurred in $2007(n=4)$, with one and three occurring in 2005 and 2006, respectively (Fig. 4b). We consider the four exceptionally low values (ranging from -0.18 to -0.24 ) to be outliers in this analysis that can partly be explained by the preferential channeling of intercepted water via canopy "pour points" to the collector (Konishi et al., 2006; Ziegler et 

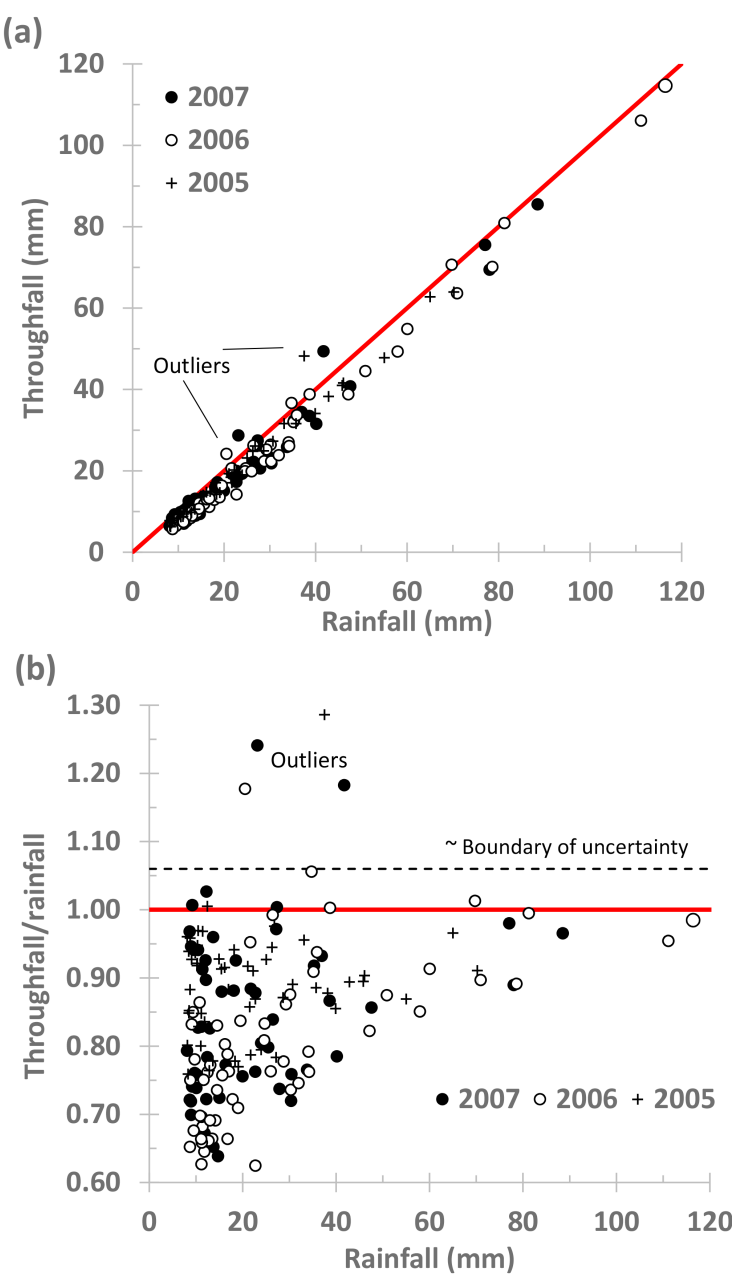

Figure 4. (a) Comparison of throughfall to runoff depths for the 3 years of study (2005-2007). (b) Throughfall fraction of rainfall for events ranging in depth from 8 to $116 \mathrm{~mm}$ during the 3year study. Uncertainty of any throughfall measurement is estimated to be $\pm 6 \%$ (indicated in the figure for the case of throughfall = rainfall). The four values labeled "outliers" are exceptionally high estimates of throughfall for which we cannot completely explain the possible errors.

al., 2009). Both the boundary of uncertainty and the outliers are shown in Fig. $4 \mathrm{~b}$.

A total of 35 events had $C_{\mathrm{i}}$ values $\geq 0.25$ (Fig. 3a). These events ranged in size from 8.7 to $32.0 \mathrm{~mm}$ (median $=12 \mathrm{~mm}$ ). The events also ranged from 0.5 to $7.4 \mathrm{~h}$ in duration, and event intensities ranged from 2 to $37 \mathrm{~mm} \mathrm{~h}^{-1}$. Three events had mean intensities $>20 \mathrm{~mm} \mathrm{~h}^{-1}$. Moisture conditions varied greatly prior to events: $\mathrm{API}_{2}$ ranged from 0 to $60 \mathrm{~mm}$.

Except for four events with anomalously low $C_{\mathrm{i}}$ values, the overall tendency was for $C_{\mathrm{i}}$ to converge towards 0 as total rainfall increased, particularly beyond $60 \mathrm{~mm}$ (Fig. 3a). However, the relationship between $C_{\mathrm{i}}$ and total rainfall was not strong (nonlinear regression; $R^{2}=0.11$; significant at $\alpha=0.05$; Fig. 3a). No meaningful relationship existed between $C_{\mathrm{i}}$ and $\mathrm{API}_{2}$, event duration, or mean event intensity (Fig. 3b-d). However, during longer events with short periods of high intensity, mean intensity would not be a good index to compare with $C_{\mathrm{i}}$.

\subsection{Canopy interception during large storms}

Because many shallow landslides occur after a high-intensity burst of rainfall that follows an initial period of lowerintensity rain (Okuda et al., 1979; Sidle and Swanston, 1982; Sidle and Chigira, 2004; Sidle and Bogaard, 2016), we focus mainly on the largest and longest events (Table 2). Eleven of the events summarized in Table 2 have total rainfall depths $>65 \mathrm{~mm}$, and one had a duration $>55 \mathrm{~h}$ (event 1 ; total rainfall $=40 \mathrm{~mm}$ ). The 11 large events have low $C_{\mathrm{i}}$ values $(-0.01$ to 0.11$)$, indicating that most rainfall was converted into throughfall (open orange circles in Fig. 3). The longduration event 1 had a relatively high $C_{\mathrm{i}}$ value $(0.14$; the triangle in Fig. 3b).

Events 54 and 158 had $C_{\mathrm{i}}$ values $\leq 0$ (Table 2). Event 54 was short-duration and high-intensity with moderately high wind speed, while event 158 had relatively low intensity and wind speed, but high surface soil moisture prior to the storm. The high-intensity and moderately high wind speed during event 54 likely generated non-vertical rainfall that may have been underestimated in the gauge above the canopy and may have dislodged and transferred rainfall from proximate trees to the plot canopies and throughfall collector troughs. The slightly negative $C_{\mathrm{i}}(-0.01)$ during event 158 was likely affected by wet conditions at the onset of the storm.

Five events had canopy interception values ranging from 0.02 to 0.05 (99, 156, 48, 56, 63; Table 2), indicating very limited canopy interception loss during these large (65 to $116 \mathrm{~mm}$ ) events. Durations and intensities of these five events were variable, ranging from 2.4 to $38.8 \mathrm{~h}$ and 5.3 to $41.6 \mathrm{~mm} \mathrm{~h}^{-1}$, respectively. High antecedent precipitation $\left(\mathrm{API}_{2}=11\right.$ to $\left.22 \mathrm{~mm}\right)$ and maximum wind speed (2.3 to $4.2 \mathrm{~m} \mathrm{~s}^{-1}$ ) occurred prior to and during four of these events, while event 63 had the driest antecedent conditions (Table 2).

The large event with greatest interception $\left(1 ; C_{\mathrm{i}}=0.14\right)$ had the driest antecedent conditions $\left(\mathrm{API}_{2}=0 \mathrm{~mm}\right)$ of all large events considered and very low maximum wind speed $\left(1.9 \mathrm{~m} \mathrm{~s}^{-1}\right)$. This 2-day event contained 13 gaps $(1.0-2.7 \mathrm{~h})$ where no throughfall was generated. Because of these conditions and the relatively small total rainfall depth $(40 \mathrm{~mm})$, canopy interception was likely higher than that for the other large events (Fig. 3b). Some canopy evaporation likely occurred during this event, but we cannot quantify this value. We included event 1 as a "large" event because of its exceptionally long duration $(>56 \mathrm{~h}$ ).

The remaining four large events with intermediate $C_{\mathrm{i}}$ values ranging from 0.09 to $0.11(115,96,85$, and 26) all had relatively long durations (10.6 to $29.7 \mathrm{~h}$ ), moderate intensities (2.4 to $7.4 \mathrm{~mm} \mathrm{~h}^{-1}$ ), and relatively low maximum 
Table 2. Characteristics of 12 large/long rainfall events considered in this analysis.

\begin{tabular}{|c|c|c|c|c|c|c|c|c|c|c|c|c|c|c|}
\hline Event & $\begin{array}{r}\mathrm{RF} \\
(\mathrm{mm})\end{array}$ & $\begin{array}{r}\mathrm{TF} \\
(\mathrm{mm})\end{array}$ & $\begin{array}{l}\mathrm{Ci} \\
(-)\end{array}$ & $\begin{array}{l}D \\
\text { (h) }\end{array}$ & $\begin{array}{r}I \\
\left(\mathrm{~mm} \mathrm{~h}^{-1}\right)\end{array}$ & $\begin{array}{l}\mathrm{API}_{2} \\
(\mathrm{~mm})\end{array}$ & $\begin{array}{l}\text { Wind } \\
\left(\mathrm{ms}^{-1}\right)\end{array}$ & $\begin{array}{r}\mathrm{SM} \\
(0 \mathrm{~m}) \\
\left(\mathrm{m}^{3} \mathrm{~m}^{-3}\right)\end{array}$ & $\begin{array}{r}\mathrm{SM} \\
(1 \mathrm{~m}) \\
\left(\mathrm{m}^{3} \mathrm{~m}^{-3}\right)\end{array}$ & $\begin{array}{r}\mathrm{SM} \\
(2 \mathrm{~m}) \\
\left(\mathrm{m}^{3} \mathrm{~m}^{-3}\right)\end{array}$ & $\begin{array}{r}\text { Wetness } \\
(0 \mathrm{~m}) \\
(-)\end{array}$ & $\begin{array}{r}\text { Wetness } \\
(1 \mathrm{~m}) \\
(-)\end{array}$ & $\begin{array}{r}\text { Wetness } \\
(2 \mathrm{~m}) \\
(-)\end{array}$ & $\begin{array}{r}\text { Wetting } \max \\
\text { (m) }\end{array}$ \\
\hline 56 & 116.44 & 114.66 & 0.02 & 2.8 & 41.6 & 11 & 4.2 & 0.40 & 0.34 & 0.33 & 0.89 & 0.81 & 0.70 & 2 \\
\hline 99 & 111.14 & 106.07 & 0.05 & 16.4 & 6.8 & 16 & 3.7 & 0.45 & 0.41 & 0.37 & 0.87 & 0.81 & 0.78 & 2 \\
\hline 156 & 88.54 & 85.48 & 0.03 & 2.4 & 36.9 & 22 & 2.9 & 0.48 & 0.41 & 0.37 & 1.02 & 0.83 & 0.82 & 2 \\
\hline 85 & 78.04 & 69.43 & 0.11 & 19.3 & 4.1 & 1 & 2.2 & 0.44 & 0.41 & 0.37 & 0.89 & 0.81 & 0.70 & 2 \\
\hline 63 & 77.07 & 75.54 & 0.02 & 38.8 & 2.0 & 0 & 2.3 & 0.34 & 0.40 & 0.36 & 0.82 & 0.82 & 0.79 & 2 \\
\hline 96 & 70.95 & 63.65 & 0.10 & 29.7 & 2.4 & 52 & 2.7 & 0.46 & 0.41 & 0.37 & 0.87 & 0.83 & 0.80 & 2 \\
\hline 158 & 69.76 & 70.67 & -0.01 & 16.4 & 4.2 & 6 & 1.8 & 0.45 & 0.42 & 0.37 & 0.98 & 0.83 & 0.81 & 2 \\
\hline 48 & 65.02 & 62.81 & 0.03 & 12.2 & 5.3 & 15 & 3.0 & 0.45 & 0.39 & 0.36 & 0.87 & 0.83 & 0.83 & 2 \\
\hline 115 & 78.64 & 70.10 & 0.11 & 10.6 & 7.4 & 1 & 2.2 & 0.30 & 0.34 & 0.33 & 0.80 & 0.70 & 0.68 & 1 \\
\hline 26 & 70.22 & 63.97 & 0.09 & 18.9 & 3.7 & 0 & 2.2 & 0.34 & 0.40 & 0.37 & 0.84 & 0.81 & 0.78 & 1 \\
\hline 54 & 81.28 & 80.87 & 0.00 & 1.8 & 45.6 & 0 & 3.2 & 0.17 & 0.34 & 0.33 & 0.77 & 0.65 & 0.68 & 0 \\
\hline 1 & 39.91 & 34.13 & 0.14 & 56.6 & 0.7 & 0 & 1.9 & 0.29 & 0.34 & 0.33 & 0.72 & 0.64 & 0.68 & 0 \\
\hline
\end{tabular}

$\mathrm{RF}$ is rainfall; $\mathrm{TF}$, throughfall; $C_{\mathrm{i}}$, canopy interception; $D$, duration; $I$, mean intensity $\left(\mathrm{RF} / D\right.$ ), $\mathrm{API}_{2}, 2$-day antecedent precipitation index; wind, maximum 20 min wind speed (recorded above the canopy); $\mathrm{SM}_{\mathrm{xm}}$, soil

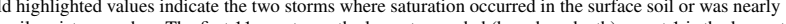
last recorded (based on depth); event 1 is the longest (ranked only 23 rd in size). Events are ranked by wetting $g_{\max }$, then rainfall depth.

wind speeds (2.2 to $2.7 \mathrm{~m} \mathrm{~s}^{-1}$ ) (Table 2 ). The main difference among these events was the much higher $\mathrm{API}_{2}$ value for event $96(52 \mathrm{~mm})$ compared to the other three events $(0$ to $1 \mathrm{~mm}$ ).

Collectively, the variation in rainfall characteristics (e.g., duration, intensity) and other hydroclimatic phenomena (e.g., maximum wind speed, $\mathrm{API}_{2}$ ) demonstrate the inherent variability in (or the measurement of) canopy interception across a range of large events. In most cases, it is difficult to pinpoint the key factor or interaction among factors dictating $C_{\mathrm{i}}$, because meteorological conditions (rainfall intensity, wind speed, canopy wetness prior to the event, canopy evaporation) vary across time and space scales that our methodology does not measure. Again, we consider the error in the interception estimate to be on the order of $6 \%$.

\subsection{Throughfall and rainfall patterns during large storms}

We also examined the temporal pattern of incident rainfall and throughfall during the six largest events (Fig. 5). This subgroup includes the three events $(54,56$, and 156) with the highest intensities $\left(36.9\right.$ to $\left.45.6 \mathrm{~mm} \mathrm{~h}^{-1}\right)$, short durations $\left(1.8\right.$ to $2.8 \mathrm{~h}$ ), and low $C_{\mathrm{i}}$ values $(0.0$ to 0.3$)$. Three other events 63,99 , and 158) had low intensities (2.0 to $\left.6.8 \mathrm{~mm} \mathrm{~h}^{-1}\right)$, long durations $(16.4$ to $38.8 \mathrm{~h})$, and a range of $C_{\mathrm{i}}$ values ( -0.01 to 0.05$)$. For events 56,99 , and 156, throughfall exceeded rainfall during early large peaks, but was generally lower than rain intensity during latter parts of these events (Fig. 5a, b, c). Short-duration event 54 was characterized by an initial burst of rainfall intensity of nearly $3 \mathrm{~mm} \mathrm{~min}^{-1}$ (Fig. 5d), which immediately translated into substantial throughfall despite the initially dry canopy $\left(\mathrm{API}_{2}=0 ; \mathrm{SM}_{0 \mathrm{~m}}=0.17\right.$; Table 2$)$. Event 158 produced a complicated pattern of throughfall response; during the initial rain burst, throughfall exceeded rainfall, but after about a $5 \mathrm{~h}$ period of little precipitation, rainfall exceeded throughfall for the rest of the event (Fig. 5f). Despite the unexpected periods of throughfall exceeding rainfall, the total event $C_{\mathrm{i}}$ value falls within our estimated $6 \%$ uncertainty threshold (Fig. 3). Throughout most of event 63, rainfall exceeded throughfall (Fig. 5e).

The three largest events $(56,99$, and 156) exhibited minor canopy storage during early, low-intensity rainfall; however, during large subsequent peaks $\left(>100 \mathrm{~mm} \mathrm{~h}^{-1}\right.$, minute by minute rates) throughfall exceeded rainfall (Fig. 5a, b, c). Moderate-to-high maximum wind speeds occurred during these three events ( 2.9 to $4.2 \mathrm{~m} \mathrm{~s}^{-1}$ ). The highest wind speed was associated with the largest rainfall event 56, during which throughfall depth was similar to rainfall depth (115 to $116 \mathrm{~mm} ; C_{\mathrm{i}}=0.02$ ). In addition, wet canopy conditions preceded these three events (API 11 to $22 \mathrm{~mm}$ ). During the early peaks of large events with relatively low intensity and wind speed (63 and 158), more rainwater was likely stored in the canopy (Figs. 5e, f). The findings of early storage agree with the generally accepted idea that canopies store a larger proportion of rainwater during the early stage of events (Xiao et al., 2000; Zeng et al., 2000; Iida et al., 2012). In five of these six large events, rainfall exceeded throughfall when intensities were $<1.0$ to $1.1 \mathrm{~mm} \mathrm{~min}^{-1}$ and, typically, throughfall exceeded rainfall when intensities were $>1.1 \mathrm{~mm} \mathrm{~min}^{-1}$; however, this pattern was not consistently found in all storms (Fig. 5).

\subsection{Soil moisture dynamics}

We examined vertical soil moisture dynamics near the soil surface and at depths of 1 and $2 \mathrm{~m}$ under the forest canopy to ascertain the effects of canopy buffering on water movement in the soil to depths where shallow landslides may occur in this area. Such a one-dimensional assessment does not capture the effects of complex topography, which can influence flow pathways and hydrologic response at depth; rather, it gives a general perspective on the potential of relatively ho- 
(a) Event no. 56

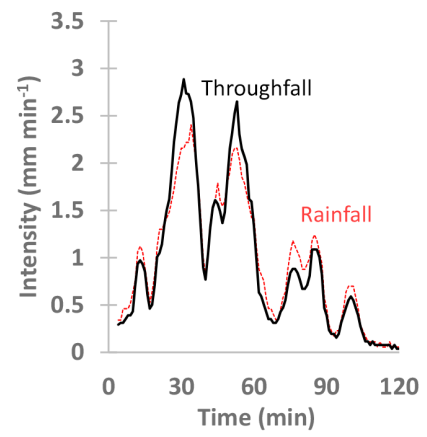

(d) Event no. 54

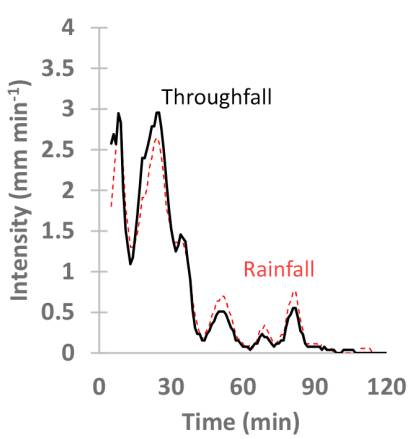

(b) Event no. 99

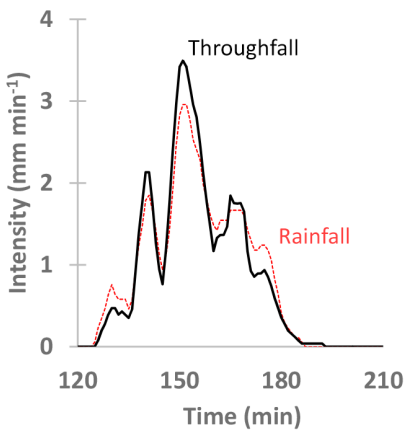

(e) Event no. 63

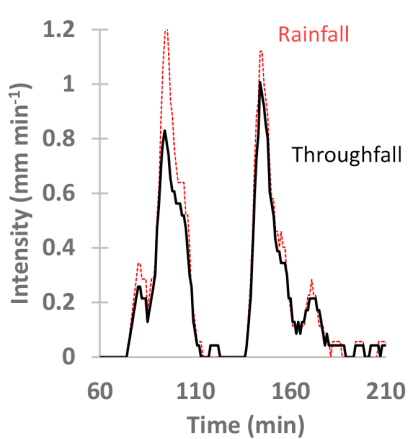

(c) Event no. 156

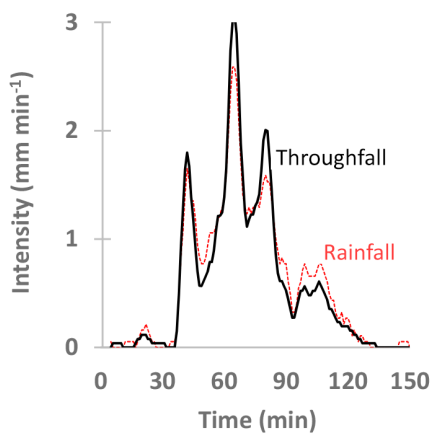

(f) Event no. 158

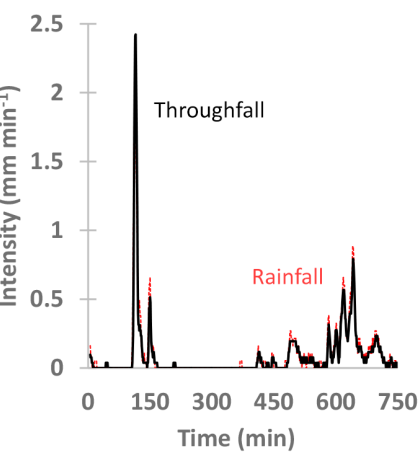

Figure 5. Five-minute running means of throughfall (solid) and rainfall (dashed) for the six largest storms (Table 2).

mogeneous soils to attenuate soil infiltration. In particular, we focus on periods during events when the canopy exerts a maximum influence on short-term incident rainfall. Such canopy interception effects have been suggested to provide benefits to slope stability during large, landslide-producing events (Rowe et al., 1999; Keim and Skaugset, 2003; Reid and Lewis, 2009). We show soil moisture dynamics for the same six events used to assess intra-storm patterns of rainfall/throughfall (Fig. 6), but we also consider changes during the other large events (Table 2). The six events include a range of dry and wet antecedent moisture conditions (e.g., $\mathrm{API}_{2}$ ranged from 0 to $22 \mathrm{~mm}$ ). Corresponding surface, $1 \mathrm{~m}$, and $2 \mathrm{~m}$ initial soil moisture ranged from 0.17 to $0.48,0.34$ to 0.42 , and 0.33 to $0.37 \mathrm{~m}^{3} \mathrm{~m}^{-3}$, respectively (Table 2 ; Fig. 6). These values indicate large differences in pre-event soil moisture near the soil surface, but not at depths where landslides may initiate in this area.

Events 56, 99, 156, and 158 are representative of relatively wet antecedent conditions. Initial surface soil moisture values for these events range from 0.40 to 0.48 (Fig. 6). Throughfall infiltration into the soil produced peaks in surface soil moisture that lagged behind throughfall peaks by typically $20-60 \mathrm{~min}$ (Fig. 6; note that soil moisture is measured every $20 \mathrm{~min}$ ). In some cases, surface soil moisture increased $>0.1 \mathrm{~m}^{3} \mathrm{~m}^{-3}$ during the event (e.g., events 56, 156, and 158). The rainfall rates triggering these increases typically exceeded $60-100 \mathrm{~mm} \mathrm{~h}^{-1}$ for $20 \mathrm{~min}$ periods (Fig. 6a, c, f). During event 99, two periods of rainfall resulted in corresponding peaks in surface soil moisture. For all four events, increases in soil moisture at a depth of $1 \mathrm{~m}$ occurred $100-180 \mathrm{~min}$ after the onset of rainfall, or 30-90 min following the maximum rainfall and/or throughfall rate (Fig. 6a, b, c, f). Soil moisture at a depth of $2 \mathrm{~m}$ increased incrementally about $1-2 \mathrm{~h}$ after the final rainfall peaks of events 156 and 158 but then tapered off after about 3-6h (Fig. 6c, f). Both events occurred under some of the wettest conditions observed (surface soil moisture $=0.45$ $0.48 \mathrm{~m}^{3} \mathrm{~m}^{-3}$ ). The short-term bursts of intensity during the two largest events $(56,116 \mathrm{~mm} ; 99,106 \mathrm{~mm})$ generated only a very minor and lagged response of soil moisture at a depth of $2 \mathrm{~m}$.

During events with drier antecedent conditions (54 and 63; $\mathrm{API}_{2}=0$ and surface soil moisture $\leq 0.34 \mathrm{~m}^{3} \mathrm{~m}^{-3}$ ), much greater wetting occurred in the surface soil (increases of $0.14-0.27 \mathrm{~m}^{3} \mathrm{~m}^{-3}$ ) compared with that during wetter antecedent conditions (Fig. 6d, e). Event 54 was characterized by an initial burst of rainfall on dry soil $\left(0.17 \mathrm{~m}^{3} \mathrm{~m}^{-3}\right)$, which rapidly elevated surface soil moisture over the next hour (Fig. 6d). Subsoil moisture during event 54 was unaffected during this shorter $(1.8 \mathrm{~h})$ event. Event 63 consisted of two rainfall/throughfall peaks that produced corresponding peaks in surface soil moisture with short lags $(20-40 \mathrm{~min})$. 
(a) Event no. 56

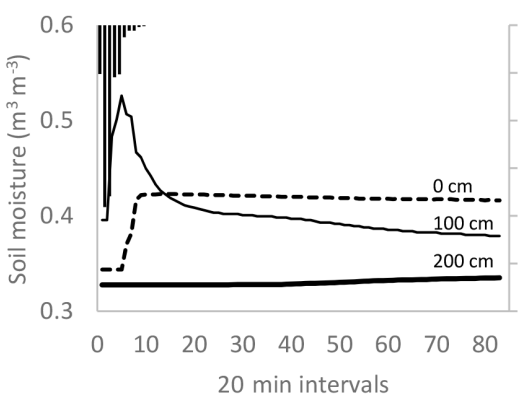

(c) Event no. 156

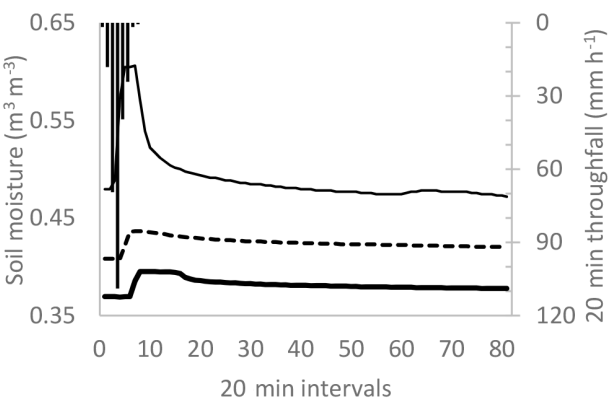

(e) Event no. 63

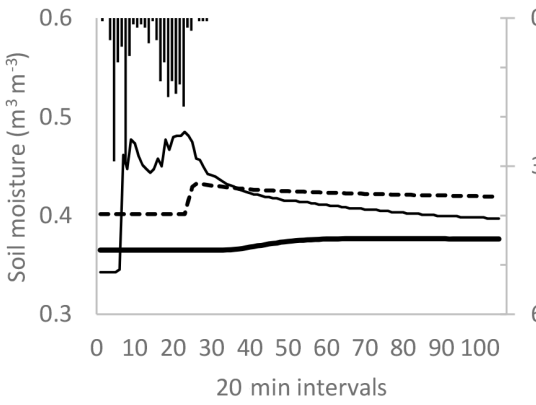

(b) Event no. 99
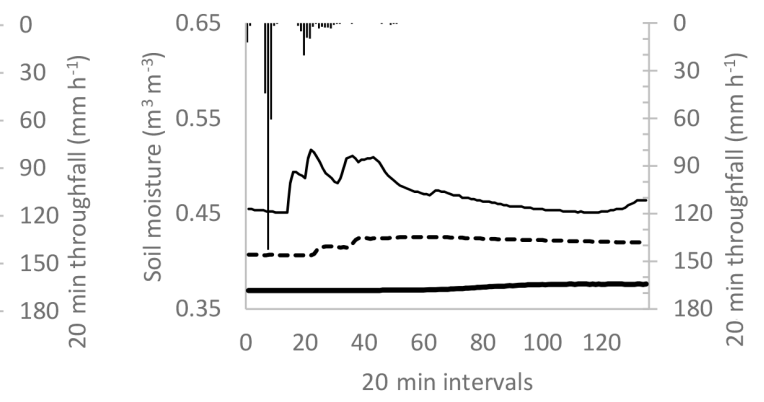

(d) Event no. 54

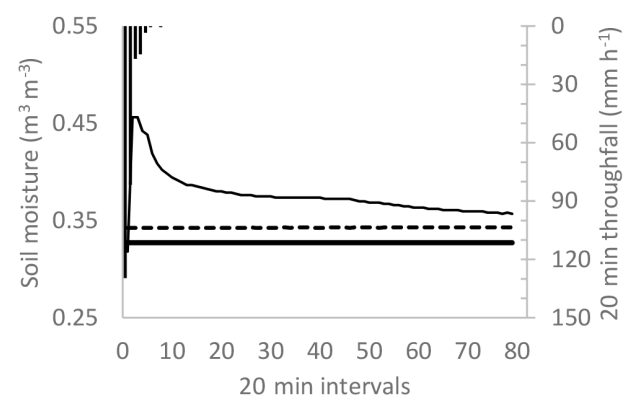

(f) Event no. 158

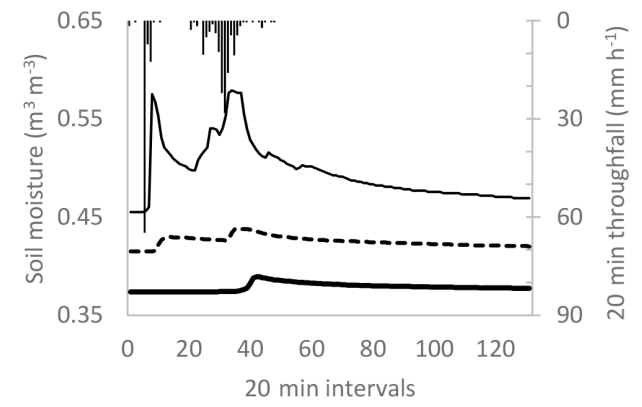

Figure 6. Volumetric soil moisture response at three depths during the six largest events (Table 2). Events with initial surface soil moisture $(0 \mathrm{~cm}) \geq 0.40 \mathrm{~m}^{3} \mathrm{~m}^{-3}$ are considered to have wet antecedent conditions: 56 (116 mm of rainfall); $99(111 \mathrm{~mm}) ; 156(89 \mathrm{~mm})$; and 158 $(78 \mathrm{~mm})$. The other two events, $54(81 \mathrm{~mm})$ and $63(77 \mathrm{~mm})$, are associated with drier antecedent moisture conditions $\left(\leq 0.30 \mathrm{~m}^{3} \mathrm{~m}^{-3}\right)$. All data are plotted as $20 \mathrm{~min}$ aggregated values. Soil moisture curves in all panels correspond to surface (thin line), $1 \mathrm{~m}$ (dashed line), and $2 \mathrm{~m}$ (thick line) depths (key shown in panel a). Each rainfall bar represents a 20 min period.

This event also caused a small but abrupt increase in soil moisture at a depth of $1 \mathrm{~m}$ just after the second rainfall peak, and a lagged and very minor increase in moisture at a depth of $2 \mathrm{~m}$. Three other large events summarized in Table 2 produced soil moisture changes at $2 \mathrm{~m}(96,85$, and 48$)$. In all cases, the maximum observed change in soil moisture at $2 \mathrm{~m}$ was only on the order of $0.03 \mathrm{~m}^{3} \mathrm{~m}^{-3}$.

Six of the eight large events that increased soil moisture at a depth of $2 \mathrm{~m}$ had very wet surface conditions (surface soil moisture values $\geq 0.44 \mathrm{~m}^{3} \mathrm{~m}^{-3}$; Table 2 ; wetting $\max _{\text {ax }}$ ). Together with these wet surface conditions, total depth of throughfall (or rainfall) appeared to be more important than event intensity in propagating water fluxes to a depth of
$2 \mathrm{~m}$. In contrast, the two events that only affected surface soil moisture had initial soil moisture values of 0.17 $0.29 \mathrm{~m}^{3} \mathrm{~m}^{-3}\left(\mathrm{API}_{2}=0.0\right.$ for both events; Table 2$)$. Throughfall depths during these drier antecedent conditions ranged from 34 to $81 \mathrm{~mm}$. Event 54 had the highest average event intensity $\left(45.6 \mathrm{~mm} \mathrm{~h}^{-1}\right)$ but produced no increases in subsoil moisture. In the intermediate range of responses, some events with initial soil moisture conditions ranging from 0.30 to $0.40 \mathrm{~m}^{3} \mathrm{~m}^{-3}$ produced soil moisture increases down to a depth of $1 \mathrm{~m}$ for a variety of throughfall inputs $(64-115 \mathrm{~mm})$ occurring over 2.8 to $18.9 \mathrm{~h}$ (Table 2). Observed changes in soil moisture at $1 \mathrm{~m}$ were on the order of $0.02-0.08 \mathrm{~m}^{3} \mathrm{~m}^{-3}$. Saturated or nearly saturated conditions in surface soils oc- 
(a) All events

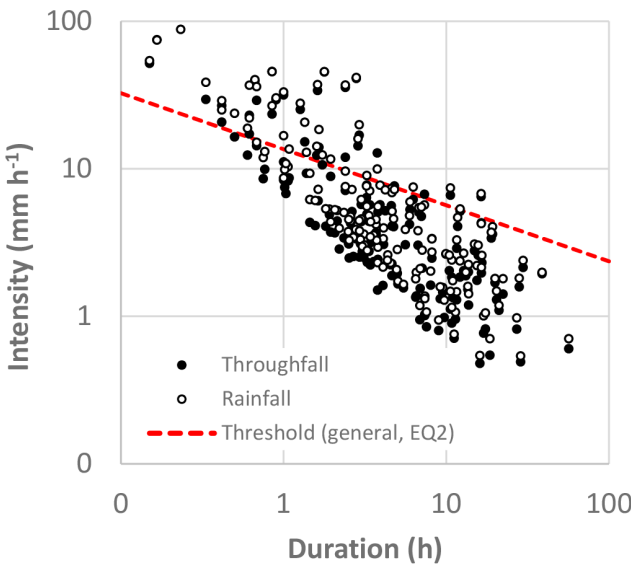

(c) $\mathrm{API}_{2}>20 \mathrm{~mm}$ (wet)

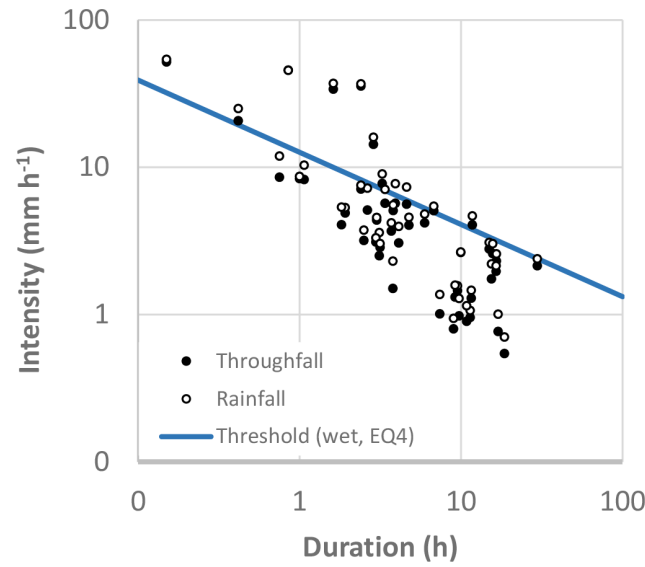

(b) $\mathrm{API}_{2}<20 \mathrm{~mm}$ (dry)

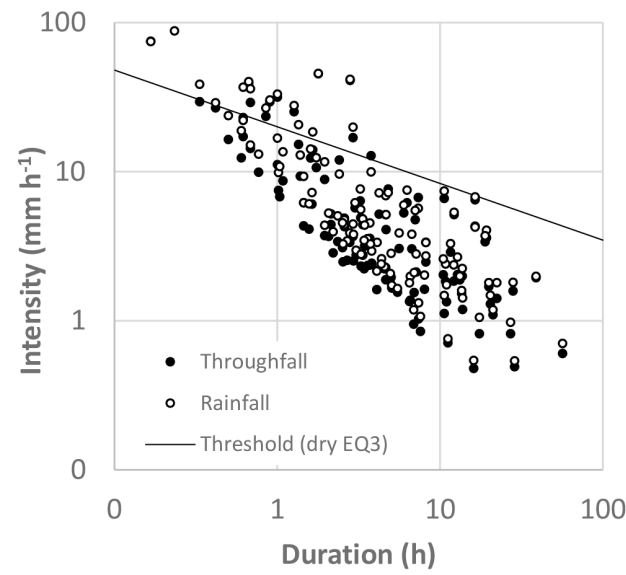

(d) Large events

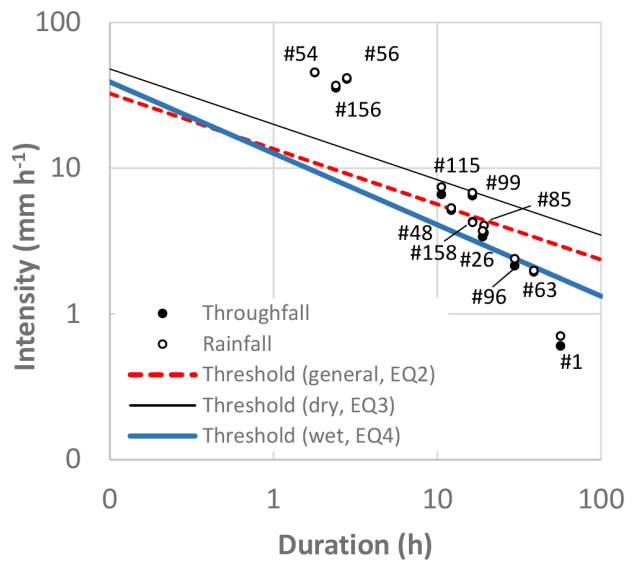

Figure 7. Comparison of event rainfall (open circles) and throughfall (solid circles) intensity-duration relationships with modified Caine thresholds for shallow landslide initiation. (a) All 167 events are plotted against the general threshold (Eq. 2). (b) Events associated with dry conditions $\left(\mathrm{API}_{2}<20 \mathrm{~mm}\right.$ ) are plotted against the threshold defined by Eq. (3). (c) Events associated with wet conditions (API $\left.2 \geq 20 \mathrm{~mm}\right)$ are plotted against the threshold defined by Eq. (4). (d) The 12 largest storms summarized in Table 2 are plotted against all thresholds (Eqs. 2-4). Some apparently missing throughfall data points plot behind their paired corresponding rainfall value.

curred during only two events (156 and 158), both of which had high moisture $\left(0.45-48 \mathrm{~m}^{3} \mathrm{~m}^{-3}\right)$ prior to the events. Even during the largest events, soil moisture contents were well below saturation at depths of 1 and $2 \mathrm{~m}$ (Table 2).

\subsection{Rainfall intensity-duration landslide thresholds}

To further assess the potential of the monitored events to initiate shallow landslides, we compared incident rainfall and throughfall to three conservative intensity-duration landslide threshold relationships (Eqs. 2, 3, and 4). Considering all 167 events, regardless of antecedent rainfall, 37 rainfall events exceeded the threshold (Eq. 2) for potential landslide initiation, while throughfall from 30 events fell on or above this threshold (Fig. 7a). This difference of 7 events is associated with 10 events with rainfall $>$ throughfall (positive canopy interceptions ranging from 0.03 to 0.34 ) and 3 events with throughfall $>$ rainfall (negative $C_{\mathrm{i}}$ ranging from -0.06 to -0.24 ). Five of these events had rainfall depths $>25 \mathrm{~mm}$ and six had intensities $>10 \mathrm{~mm} \mathrm{~h}^{-1}$ (not shown). Only one had an $\mathrm{API}_{2}$ value $>20 \mathrm{~mm}$ : event 80 , with $29 \mathrm{~mm}$ of rainfall during a period of $3.3 \mathrm{~h}\left(9 \mathrm{~mm} \mathrm{~h}^{-1}\right)$ and a $C_{\mathrm{i}}$ of 0.14 (not shown).

We segregated the 167 events into those preceded by dry and wet conditions to compare with Eqs. (3) and (4) (Fig. 7b, c). A total of 120 events were preceded by dry conditions ( $\left.\mathrm{API}_{2} \leq 20 \mathrm{~mm}\right) ; 47$ events were preceded by wet conditions $\left(\mathrm{API}_{2}>20 \mathrm{~mm}\right)$. For dry conditions, 16 and 12 rainfall and throughfall events, respectively, plotted above the corresponding threshold (Eq. 3). For the events where both rainfall and throughfall were above the threshold, du- 
rations did not exceed $3 \mathrm{~h}$ and intensities were greater than $26.7 \mathrm{~mm} \mathrm{~h}^{-1}$ (Fig. 7b). Events where rainfall exceeded the threshold but throughfall did not were characterized by low-to-moderate rainfall depths (12-30 mm), appreciable antecedent rainfall $\left(\mathrm{API}_{2}=7-18 \mathrm{~mm}\right.$; except for one event with $0 \mathrm{~mm}$ ), positive $C_{\mathrm{i}}$ values $(0.07-0.38)$, and short durations $(0.3-1.7 \mathrm{~h})$. In contrast, 12 and 9 rainfall and throughfall events, respectively, plotted above the threshold for wet conditions (Eq. 4; Fig. 7c). The nine events with throughfall above the threshold were variable in length $(0.42-11.8 \mathrm{~h})$ and average storm intensity $\left(4.7-54.1 \mathrm{~mm} \mathrm{~h}^{-1}\right)$. The three events in which incident rainfall exceeded the threshold but throughfall did not were similar in canopy interception $\left(C_{\mathrm{i}}=0.20-0.23\right)$, duration $(3.4-4.6 \mathrm{~h})$, and event intensity $\left(7.1-7.7 \mathrm{~mm} \mathrm{~h}^{-1}\right)$. Nearly all of the 12 largest events (Table 2) plotted on or above the threshold for wet conditions (Eq. 4; Fig. 7d). The long-duration event 1 (56.6 h) plotted well below all thresholds (Fig. 7d). Throughfall for three events $(54,56$, and 156) plotted well above the threshold for dry conditions, demonstrating their potential for landslide generation, despite having relatively short durations (about 2-3 h) (Table 2; Fig. 7d). Collectively, these comparisons show the limited potential of canopy interception to reduce the probability of landslide initiation during large storms (e.g., those listed in Table 2), particularly under wet antecedent conditions.

\section{Discussion}

Our estimated 3-year interception loss from a tropical secondary forest in northern Thailand based on 167 storms with total precipitation $\geq 8 \mathrm{~mm}$ was $12 \%$. Interception losses for all individual events ranged from -29 to $38 \%$ and from -1 to $11 \%$ during the 11 largest storms. Overall, we found that events with larger total precipitation had lower rates of interception compared to smaller events (albeit weakly correlated), which agrees with most other studies (Filoso et al., 1999; Keim et al., 2004; Germer et al., 2006; Reid and Lewis, 2009; Bäse et al., 2012). The total interception loss $\left(C_{\mathrm{i}}>\right.$ throughfall rate) is quite variable, especially during small events; however, based on data in Fig. 3, the upper limits of interception loss appear to be about $35 \%$ for small events increasing to nearly no loss in the largest events. Given the spatially distributed gutter system we employed to collect throughfall under this secondary forest stand, we believe our estimates are realistic within a measurement error of about $6 \%$.

The measured interception losses in this tropical secondary dipterocarp forest are on the low side of most ranges reported for temperate and semiarid canopies (Xiao et al., 2000; Iida et al., 2005; Reid and Lewis, 2007; Kato et al., 2013; Allen et al., 2014; Swaffer et al., 2014; Nanko et al., 2016). However, our values and variabilities are very similar to those reported in an open tropical Brazilian rainforest with many palm trees $(10.2 \pm 5.6 \%)$ where similar magnitudes and numbers of storms were recorded (Germer et al., 2006). Interception losses in other native and secondary Amazonian forests have been reported in the range of about 6 to $22 \%$ (Lloyd and Marques, 1988; Elsenbeer et al., 1994; Filoso et al., 1999; Tobón Marin et al., 2000; Bäse et al., 2012; Zanchi et al., 2015). Several studies in both native and plantation forests in southeast Asia that experience monsoon storms reported similarly low interception losses in the range of about 7 to $20 \%$ (Sinun et al., 1992; Dykes, 1997; Konishi et al., 2006; Ziegler et al., 2009; Tanaka et al., 2015).

The slightly lower values of interception we measured may reflect a combination of factors that vary among individual events. Stable isotope differences between throughfall and rainfall during low-intensity events showed the complexity of pre-event storage on contributions to throughfall in a conifer forest in the Oregon Cascades but indicate that the release of residual water stored in canopies may be significant (Allen et al., 2014). Given the wet, humid conditions at the Thailand site, it is possible that pre-event canopy wetness may have augmented throughfall during large events. In other large events, it appears that the higher maximum 20 min wind speed was a factor in dislodging water from within the plot and surrounding canopies and resulted in limited interception. Many studies have shown that storage of water in tree canopies is reduced under windy conditions (Hutchings et al., 1988; Llorens and Gallart, 2000; Xiao et al., 2000; Keim and Skaugset, 2003; Kato et al., 2013). While wind can increase evaporation and dry the canopy during storms (Kelliher et al., 1992; Xiao et al., 2000), it may increase measured throughfall by increasing canopy drip, changing the angle of incoming rainfall, and capturing wind-blown rain from adjacent trees (Xiao et al., 2000; Ziegler et al., 2009). Non-vertical rainfall, which is common during windy conditions associated with many monsoon storms, is also often under-recorded by small, standard gauges (Kamph and Burges, 2010). Finally, canopy "drip points" or "pour points" may develop, where intercepted water is channeled preferentially to the collector (Konishi et al., 2006; Ziegler et al., 2009); these points are dynamic and change as canopies develop and environmental conditions change during the storm. Throughfall measurements during four moderate-sized events with anomalously low $C_{\mathrm{i}}$ values (indicated as outliers in Figs. 3 and 4) may have been affected by a combination of these factors.

It should be noted that we did not account for losses due to interception of litter cover on the forest floor, which in some ecosystems can be significant (Kelliher et al., 1992; Gerrits et al., 2010). Such interception would only be affected by forest removal and subsequent regeneration if significant site disturbance occurred during logging.

We found no strong evidence of canopy smoothing of incident rainfall on throughfall during large events; such intensity smoothing has been suggested as a factor in moderating peak pore water pressures within soil mantles, thus 
reducing the risk of shallow landslides (Rowe et al., 1999; Keim and Skaugset, 2003; Keim et al., 2004; Reid and Lewis, 2009). The throughfall data we present from northern Thailand are unique in terms of number of events and temporal resolution, which allows us to better assess peak responses related to rainfall inputs. During six of the largest events that would potentially trigger landslides, throughfall intensity $( \pm$ our estimated uncertainty threshold) actually exceeded rainfall intensity during the largest storm peaks in five of the six events (Fig. 5). In event 63, which had the lowest peak intensity of these six events, peak rainfall intensity exceeded peak throughfall intensity. Although the peak intensities of rainfall and throughfall differed amongst events, little smoothing (i.e., flattening) of throughfall peaks relative to rainfall peaks was evident. While a few studies have alluded to intensity smoothing by forest canopies on throughfall (Xiao et al., 2000; Keim et al., 2004, 2006; Nanko et al., 2016), only one presented specific evidence of intra-storm smoothing (i.e., flattening) of rainfall peaks (Xiao et al., 2000). The only storm that Xiao et al. (2000) presented was small $(13 \mathrm{~mm})$ and low-intensity compared to the monsoon events in northern Thailand, and only throughfall under one oak was assessed. In some cases, the smoothing effects are derived through modeling (Keim et al., 2004, 2006), but even in these cases, the effects on pore water pressure in the substrate during events were small.

Furthermore, only soil moisture in the surface horizon was responsive to individual rainfall peaks during the same six large events shown in Fig. 5. Soil moisture increases at the depth of $1 \mathrm{~m}$ were highly dampened, lagged the rainfall peak by nearly an hour or more, and soil moisture never approached saturation (Fig. 6). Because of the absence of a constricting permeability layer at shallow depths in these deeply weathered soils, most potential failure planes occur at depths of $2 \mathrm{~m}$ or greater. At the depth of $2 \mathrm{~m}$, only very minor increases in soil moisture $\left(\leq 0.01-0.02 \mathrm{~m}^{3} \mathrm{~m}^{-3}\right)$ were recorded during five of the six large events, and no soil moisture response at $2 \mathrm{~m}$ was measured during event 54 (Fig. 6). This dampened or lack of soil moisture response at depth shows that even during events with higher peak rainfall versus throughfall inputs (e.g., event 63; Fig. 5e), the impact on pore water pressure at the depth of a potential failure plane would be small (Fig. 6e). We did not assess the effect of slope shape on soil moisture response. It is possible that higher canopy interception during small events just preceding (e.g., one to a few days) a large storm could mitigate soil moisture response at depth to some extent.

The comparisons of incident rainfall and throughfall to established intensity-duration landslide threshold relationships allow us to compare the potential for rainfall-initiated landslides in secondary tropical forests (throughfall measurements) versus cutover or converted sites (incident rainfall). Most large events had intensity-duration relationships that fell above global thresholds for potential landslide initiation during wet conditions. The three events that greatly ex- ceeded the most conservative threshold (i.e., for dry conditions) were very short-duration $(2-3 \mathrm{~h})$, high average intensity $\left(37-46 \mathrm{~mm} \mathrm{~h}^{-1}\right)$ storms. Considering that peak rainfall intensity was generally not much greater than corresponding peak throughfall intensity during large events and that soil moisture response at depths where landslides may initiate $(\geq 1 \mathrm{~m})$ did not respond rapidly to peak rainfall inputs, it appears that canopy interception would have little influence on mitigating pore water accretion at depths where shallow landslides typically occur in this secondary tropical forest. Furthermore, similar behavior of incident rainfall and throughfall during individual events with respect to intensity-duration thresholds for landslide initiation supports our conclusion that canopy interception at the site has negligible influence on landslides for the rainfall conditions we observed.

\section{Limitations and recommendations}

There are some important limitations to our methods. In a prior study, Ziegler et al. (2009) compared the same troughs used herein with several movable tipping-bucket gauges, finding no statistical difference between the two approaches. However, in the previous study, total event precipitation was examined rather than changes occurring minute to minute over the course of storms. We caution that the trough method may create a somewhat confusing signal because of the areaintegrated pattern of throughfall and because of the delayed response for water captured in the trough to flow through the trough, compared to an individual rain gauge placed above the canopy. Nevertheless, at high rates of throughfall, trough flow would be more efficient. Additionally, estimates of both throughfall and rainfall have errors. Measurements by tipping-bucket rain gauges installed above a canopy are affected by turbulent exchange at this interface, and wind affects rainfall catch (Kamph and Burges, 2010). As mentioned before, the throughfall troughs had a large associated splash error during high-intensity events. While our attempt to correct the splash error resulted in reasonable total event values, individual minute by minute values could still have substantial errors; these would affect the time series we compare with measured rainfall (Fig. 6). However, such limitations are inherent in all studies reported in the literature (albeit typically not articulated).

In future experiments, we urge researchers to minimize uncertainties by (a) using troughs that are deeper to minimize splash loss, (b) collecting ambient rainfall in more than one location, preferably with gauges positioned just above ground level with appropriate wind shields to minimize wind effects, (c) taking more throughfall measurements, potentially by employing other types of collection devices to help interpret the measurements, and (d) performing a rigorous assessment of splash losses to facilitate error correction (our splash error data are few). We also encourage researchers 
to spend time in the forest plots during events recording the various types of phenomena that may affect the capture of throughfall over time to help with the interpretation of data. Here, we reemphasize that throughfall reaching the forest floor is highly variable in space and time. Multistored canopies can create wet and dry zones below them, which change over the course of a storm with respect to variable wind direction, changes in rainfall characteristics (rate, drop size), and changes in canopy wetness (Konishi et al., 2006). The oddities apparent in the data of some of our recorded storms (e.g., higher throughfall than rainfall during some periods, but not others) may possibly be related to inadequacies in our error correction; however, these may also be realistic. For example, they may result from wind-driven rain captured by portions of a large tree and then channeled directly to the throughfall trough (as was documented at the prior study site; Ziegler et al., 2009).

We believe that these uncertainties do not undermine the integrity of our conclusions. While the uncertainties may prevent us from producing a high-precision budget of the portion of rainfall converted to throughfall at minute by minute scales, they do allow us to address the primary goals of this investigation, which are to assess whether secondary tropical canopies intercept sufficient rainwater during large storms to mitigate landslide initiation compared to open areas.

\section{Conclusions}

Our examination of the effects of canopy interception in a secondary dipterocarp forest of northern Thailand on the potential for shallow landslide initiation revealed some interesting findings. Compared to temperate and semi-arid forests, throughfall in our secondary forest plot during events was relatively high owing to high rainfall intensities associated with monsoon storms, wind effects (transferring rainwater from surrounding trees and causing undercatch of precipitation), wet and humid antecedent conditions, and preferential channeling of canopy drip into collection troughs. Nevertheless, our throughfall measurements are in line with many values reported from both native and secondary forests in Amazonia and elsewhere in southeast Asia.

Few studies have reported intra-storm comparisons of incident rainfall and throughfall at temporal resolutions that could be used to assess the effects of canopy interception on shallow landslide initiation (i.e., $\leq 1 \mathrm{~h}$ ). While many of these investigations note smoothing effects of canopy interception on incident rain intensity, none show any physical evidence that canopy smoothing lowered soil moisture or pore pressures at depths that would reduce landslide susceptibility. Although our throughfall results from many large and intense monsoon events in northern Thailand were affected by instrumental errors (common in all studies of this type), our results indicate that these secondary tropical forest canopies have relatively small smoothing effects on incident rainfall peaks during high-intensity rainfall events. We also show that soil moisture response is quite dampened or even nonresponsive at depths where potential failure planes exist in this region $(\geq 2 \mathrm{~m})$. These data, coupled with our analysis of mean rain intensity-duration thresholds that are used to estimate lower global limits of rainfall conditions that may trigger shallow landslides, show that both rainfall and throughfall for the 11 largest events exceeded or reached thresholds for wet antecedent conditions and plotted very closely on the intensity-duration graph (Fig. 6d). There is little evidence that canopy interception during large events in this secondary tropical forest has a significant mitigating effect on shallow landslides. It is possible that rainfall intercepted during a small event just prior to a large storm could alter antecedent soil moisture and possibly increase pore water pressure response at depth to a small degree. More likely and much better documented anthropogenic causes of landslide increases in similar tropical environments include root strength deterioration following timber harvesting, forest conversion, swidden agriculture (Harper, 1993; Sidle et al., 2006; DeGraff et al., 2012), roads and trails (Douglas et al., 1999; Chappell et al., 2004; Sidle and Ziegler, 2012), and possibly the effects of increased antecedent soil moisture following clearing or conversion of forest cover (Sidle et al., 2006; Sidle and Bogaard, 2016).

\section{Data availability}

We have made the data file available at the following website address: https://www.adziegler.com/data/.

Competing interests. The authors declare that they have no conflict of interest.

Acknowledgements. Gratitude is expressed to Aaron Pruitt for his assistance in data analysis. We also acknowledge Tom Giambelluca, Mike Nullet, and Jefferson Fox for their efforts in the establishment of the Mae Sa experiment site. The constructive suggestions and critiques by several external reviewers and the editor are much appreciated.

Edited by: I. van Meerveld

Reviewed by: three anonymous referees

\section{References}

Aleotti, P.: A warning system for rainfall-induced shallow failures, Eng. Geol., 73, 247-265, 2004.

Allen, S. T., Brooks, J. R., Keim, R. F., Bond, B. J., and McDonnell, J. J.: The role of pre-event canopy storage in throughfall and stemflow by using isotopic tracers, Ecohydrology, 7, 858-868, 2014. 
Bannwarth, M. A., Sangchan, W., Hugenschmidt, C., Lamers, M., Ingwersen, J., Ziegler, A. D., and Streck, T.: Pesticide transport simulation in a tropical catchment by SWAT, Environ. Pollut., 191, 70-79, 2014a.

Bannwarth, M. A., Hugenschmidt, C., Sangchan, W., Lamers, M., Ingwersen, J., Ziegler, A. D., and Streck, T.: Simulation of stream flow components in a mountainous catchment in northern Thailand with SWAT, using the ANSELM calibration approach, Hydrol. Process., 29, 1340-1352, doi:10.1002/hyp.10268, 2014 b.

Bäse, F., Elsenbeer, H., Neill, C., and Krusche, A. V.: Differences in throughfall and net precipitation between soybean and transitional tropical forest in the southern Amazon, Brazil, Agric. Ecosys. Environ., 159, 19-28, 2012.

Caine, N.: Rainfall intensity-duration control of shallow landslides and debris flows, Geograf. Ann., 62A, 23-27, 1980.

Calder, I. R. and Kidd, C. H. R.: A note on the dynamic calibration of tipping-bucket gauges, J. Hydrol., 39, 383-386, 1978.

Chappell, N. A., Douglas, I., Hanapi, J. M., and Tych, W.: Sources of suspended sediment within a tropical catchment recovering from selective logging, Hydrol. Process., 18, 685-710, 2004.

Crockford, R. and Richardson, D.: Partitioning of rainfall into throughfall, stemflow and interception: Effect of forest type, ground cover and climate, Hydrol. Process., 14, 2903-2920, 2000.

Dahal, R. K. and Hasegawa, S.: Representative rainfall thresholds for landslides in the Nepal Himalaya, Geomorphology, 100, 429443, 2008.

DeGraff, J. V., Sidle, R. C., Ahmad, R., and Scatena, F. N.: Recognizing the importance of tropical forests in limiting rainfallinduced debris flows, Environ. Earth Sci., 67, 1225-1235, doi:10.1007/s12665-012-1580-8, 2012.

Dhakal, A. S. and Sullivan, K.: Shallow groundwater response to rainfall on a forested headwater catchment in northern coastal California: implications of topography, rainfall, and throughfall intensities on peak pressure head generation, Hydrol. Process., 28, 446-463, 2014.

Douglas, I., Biden, K., Balamurugan, G., Chappell, N. A., Walsh, R. P. D., Greer, T., and Sinun, W.: The role of extreme events in the impacts of selective tropical forestry on erosion during harvesting and recovery phases at Danum Valley, Sabah, Philos. T. R. Soc. Lond., 354, 1749-1761, 1999.

Dykes, A. P.: Rainfall interception from a lowland tropical rainforest in Brunei, J. Hyrol., 200, 260-279, 1997.

Elsenbeer, H., Cassel, D. K., and Zuniga, L.: Throughfall in the terra firme forest of western Amazonia, J. Hydrol., 32, 30-45, 1994.

Fernandes, N. F., Netto, A. L. C., and Lacerda, W. A.: Subsurface hydrology of layered colluvium mantles in unchanneled valleys south-eastern Brazil, Earth Surf. Proc. Land., 19, 609-626, 1994.

Filoso, S., Willimas, M. R., and Melack, J. M.: Composition and deposition of throughfall in a flooded forest archipelago (Negro River, Brazil), Biogeochem., 45, 169-195, 1999.

Germer, S., Elsenbeer, H., and Moraes, J. M.: Throughfall and temporal trends of rainfall redistribution in an open tropical rainforest, south-western Amazonia (Rondônia, Brazil), Hydrol. Earth Syst. Sci., 10, 383-393, doi:10.5194/hess-10-383-2006, 2006.

Gerrits, A. M. J., Pfister, L., and Savenije, H. H. G.: Spatial and temporal variability of canopy and forest floor interception in a beech forest, Hydrol. Process., 24, 3011-3025, doi:10.1002/hyp.7712, 2010 .
Ghestem, M., Sidle, R. C., and Stokes, A.: The influence of plant root systems on subsurface flow: Implications for slope stability, BioScience, 61, 869-879, 2011.

Godt, J. W., Baum, R. L., and Lu, N.: Landsliding in partially saturated materials, Geophys. Res. Lett., 36, L02403, doi:10.1029/2008GL035996, 2009.

Gray, D. H. and Megahan, W. F.: Forest vegetation removal and slope stability in the Idaho Batholith, Res. Pap. INT-271, 23 pp., For. Serv., US Dep. of Agric., Ogden, Utah, 1981.

Greco, R., Comegna, L., Damiano, E., Guida, A., Olivares, L., and Picarelli, L.: Hydrological modelling of a slope covered with shallow pyroclastic deposits from field monitoring data, Hydrol. Earth Syst. Sci., 17, 4001-4013, doi:10.5194/hess-17-40012013, 2013.

Guzzetti, F., Peruccacci, S., Rossi, M., and Stark, C. P.: The rainfall intensity-duration control of shallow landslides and debris flows: an update, Landslides, 5, 3-17, 2008.

Harp, E. L., Wells II, W. G., and Sarmiento, J. G.: Pore pressure response during failure in soils, Geol. Soc. Am. Bull., 102, 428438, 1990.

Harper, S. B.: Use of approximate mobility index to identify areas susceptible to landsliding by rapid mobilization to debris flows in southern Thailand, J. Southe. Asian. Earth, 8, 587-596, 1993.

Humphrey, M. D., Istok, J. D., Lee, J. Y., Hevesi, J. A., and Flint, A. L.: A new method for automated dynamic calibration of tippingbucket rain gauge, J. Atmos. Ocean. Tech. 14, 1513-1519, 1997.

Hutchings, N. J., Milne, R., and Crowther, J. M.: Canopy storage capacity and its vertical distribution in a Sitka spruce canopy, J. Hydrol., 104, 161-171, 1988.

Iida, S., Tanaka, T., and Sugita, M.: Change of interception process due to the succession from Japanese red pine to evergreen oak, J. Hydrol., 315, 154-166, 2005.

Iida, S., Tamai, K., Shimizu, T., Nobuhiro, T., Kabeya, N., and Shimizu, A.: Characteristics of process of rainfall interception in a Japanese cedar forest within the Tsukuba Experimental Watershed, Japan, Kanto Forestry Res., 63, 121-124, 2012 (in Japanese with English abstract).

Imaizumi, F., Sidle, R. C., and Kamei, R.: Effects of forest harvesting on occurrence of landslides and debris flows in steep terrain of central Japan, Earth Surf. Proc. Land., 33, 827-840, 2008.

Kamph, S. K. and Burges, S. J.: Quantifying the water balance in a planar hillslope plot: Effects of measurement errors on flow prediction, J. Hydrol., 380, 191-202, 2010.

Kato, H., Onda, Y., Nanko, K., Gomi, Yamanaka, T., and Kawaguchi, S.: Effect of canopy interception on spatial variability and isotopic composition of throughfall in Japanese cypress plantations, J. Hydrol., 504, 1-11, 2013.

Keim, R. F. and Skaugset, A. E.: Modelling effects of forest canopies on slope stability, Hydrol. Process., 17, 1457-1467, 2003.

Keim, R. F., Skaugset, A. E., Link, T. E., and Iroumé, A.: A stochastic model of throughfall for extreme events, Hydrol. Earth Syst. Sci., 8, 23-34, doi:10.5194/hess-8-23-2004, 2004.

Keim, R. F., Tromp-van Meerveld, H. J., and McDonnell, J. J.: A virtual experiment on the effects of evaporation and intensity smoothing by canopy interception on subsurface stormflow generation, J. Hydrol., 327, 352-364, 2006. 
Kelliher, F. M., Whitehead, D., and Pollock, D. S.: Rainfall interception by trees and slash in a young Pinus radiate D. Don stand, J. Hydrol., 131, 187-204, 1992.

Konishi, S., Tani, M., Kosugi, Y., Takanashi, S., Mohd Md, S., Abdul Rahim, N., Niiyama, K., and Okuda, T.: Characteristics of spatial distribution of throughfall in a lowland tropical rainforest, Peninsular Malaysia, Forest Ecol. Mgmt., 224, 19-25, 2006.

Kuriakose, S. L., Jetten, V. G., van Westen, C. J., Sankar,G., and van Beek, L. P. H.: Pore water pressure as a trigger of shallow landslides in the Western Ghats of Kerala, India: some preliminary observations from an experimental catchment, Physical Geog., 29, 374-386, 2008.

Lacerda, W. A.: Landslide initiation in saprolite and colluvium in southern Brazil: Field and laboratory observations, Geomorphology, 87, 104-119, 2007.

Larsen, M. C. and Simon, A.: A rainfall intensity-duration threshold for landslides in a humid-tropical environment, Puerto Rico, Geogr. Ann. A, 75, 13-23, 1993.

Llorens, P. and Gallart, F.: A simplified method for forest water storage capacity measurement, J. Hydrol., 240, 131-144, 2000.

Lloyd, C. R. and de O. Marques, A.: Spatial variability of throughfall and stemflow measurements in Amazonian rainforest, Agric. For. Meteorol., 42, 63-73, 1988.

Marsalek, J.: Calibration of the tipping-bucket raingage, J. Hydrol., 53, 343-354, 1981.

Megahan, W. F.: Hydrologic effects of clearcutting and wildlife on steep granitic slopes in Idaho, Water Resour. Res., 19, 811-819, 1983.

Nanko, K., Onda, Y., Kato, H., and Gomi, T.: Immediate change in throughfall spatial distribution and canopy water balance after heavy thinning in a dense mature Japanese cypress plantation, Ecohydrology, 9, 300-314, 2016.

Okuda, S., Ahida, K., Gocho, Y., Okunishi, K., Sawada, T., and Yokoyama, K.: Characteristics of heavy rainfall and debris hazard, J. Nat. Disaster Sci., 1, 41-55, 1979.

Pypker, T. G., Bond, B. J., Link, T. E., Marks, D., and Unsworth, M. H.: The importance of canopy structure in controlling the interception loss of rainfall: Examples from a young and old-growth Douglas-fir forest, Agr. Forest Meteorol., 130, 113-129, 2005.

Reid, L. M. and Lewis, J.: Rates and implications of rainfall interception in a coastal redwood forest, USDA Forest Serv. Gen. Tech. Rep. PSW-GTR-194, 107-117, 2007.

Reid, L. M. and Lewis, J.: Rates, timing, and mechanisms of rainfall interception loss in a coastal redwood forest, J. Hydrol., 375, 459-470, 2009.

Roering, J., Schmidt, K. M., Stock, J. D., Dietrich, W. E., and Montgomery, D. R.: Shallow landsliding, root reinforcement, and the spatial distribution of tress in the Oregon Coast range, Can. Geotech. J., 40, 237-253, 2003.

Rowe, L. K., Marden, M., and Rowan, D.: Interception and throughfall in a regenerating stand of kanuka (Kunzea ericoides var. ericoides), East Coast region, North Island, New Zealand, and implications for soil conservation, J. Hydrol. N.Z., 38, 29-48, 1999.

Sasaki, Y., Fuijii, A., and Asai, K.: Soil creep process and its role in debris slide generation - field measurements on the north side of Tsukuba Mountain in Japan, Eng. Geol., 56, 163-183, 2000.

Schmidt, K. M., Roering, J. J., Stock, J. D., Dietrich, W. E., Montgomery, D. R., and Schaub, T.: The variability of root cohesion as an influence on shallow landslide susceptibility in the Oregon Coast Range, Can. Geotech. J., 38, 995-1024, 2001.

Schwartz, M., Cohen, D., and Or, D.: Spatial characterization of root reinforcement at stand level: Theory and case study, Geomorphology, 171-172, 190-200, 2012.

Schwarz, M., Giadrossich, F., and Cohen, D.: Modeling root reinforcement using a root-failure Weibull survival function, Hydrol. Earth Syst. Sci., 17, 4367-4377, doi:10.5194/hess-17-43672013, 2013.

Scott, R., Watts, C., Payan, J., Edwards, E., Goodrich, D. Williams, D., and Shuttleworth, W.: The understory and overstory partitioning of energy and water fluxes in an open canopy, semiarid woodland, Agr. Forest Meteorol., 114, 127-139, 2003.

Sidle, R. C.: A theoretical model of the effects of timber harvesting on slope stability, Water Resour. Res., 28, 1897-1910, 1992.

Sidle, R. C.: Influence of forest harvesting activities on debris avalanches and flows, in: Debris Flow Hazards and Related Phenomena, edited by: Jakob, M. and Hungr, O., 345-367, SpringerPraxis, Heidelberg, 2005.

Sidle, R. C. and Bogaard, T. A.: Dynamic earth system and ecological controls of rainfall-initiated landslides, Earth-Sci. Rev., 159, 275-291, doi:10.1016/j.earscirev.2016.05.013, 2016.

Sidle, R. C. and Chigira, M.: The July 20, 2003, landslides and debris flows in southern Kyushu, Japan, Eos, Trans., Am. Geophys. Union, 85, 145-151, 2004.

Sidle, R. C. and Ochiai, H.: Landslides: Processes, Prediction, and Land Use, Am. Geophysical Union, Water Resour. Monogr. No. 18, AGU, Washington, DC, p. 312, 2006.

Sidle, R. C. and Swanston, D. N.: Analysis of a small debris slide in coastal Alaska, Can. Geotech. J., 19, 167-174, 1982.

Sidle, R. C. and Wu, W.: Simulating the effect of timber harvesting on temporal and spatial distribution of shallow landslides, $\mathrm{Z}$. Geomorphol., 43, 185-201, 1999.

Sidle R. C. and Ziegler, A. D.: Elephant trail runoff and sediment dynamics in northern Thailand, J. Environ. Qual., 39, 871-881, doi:10.2134/jeq2009.0218, 2010.

Sidle, R. C. and Ziegler, A. D.: The dilemma of mountain roads, Nature Geosci., 5, 437-438, 2012.

Sidle, R. C., Ziegler, A. D., Negishi, J. N., Abdul Rahim, N., Siew, R., and Turkelboom, F.: Erosion processes in steep terrain Truths, myths, and uncertainties related to forest management in Southeast Asia, Forest Ecol. Mgmt., 224, 199-225, 2006.

Stokes, A., Atger, C., Bengough, A. G., Fourcaud, T., and Sidle, R. C.: Desirable plant root traits for protecting natural and engineered slopes against landslides, Plant Soil, 324, 1-30, 2009.

Sinun, W., Meng, W. W., Douglas, I., and Spencer, T.: Throughfall, stemflow, overland flow and throughflow in the Ula Segama rain forest, Sabah, Malaysia, Philos. T. R. Soc. B, 335, 389-395, 1992.

Swaffer, B. A., Holland, K. L., Doody, T. M., and Hutson, J.: Rainfall partitioning, tree form and measurement scale: a comparison of two co-occurring, morphologically distinct tree species in a semi-arid environment, Ecohydrology, 7, 1331-1344, 2014.

Tanaka, N., Levia, D., Igarashi, Y., Nanko, K., Yoshifuji, N., Tanaka, K., Tantasirin, C., Suzuki, M., and Kumagai, T.: Throughfall under a teak plantation in Thailand: a multifactorial analysis on the effects of canopy phenology and meteorological conditions, Int. J. Biometeorol., 59, 1145-1156, 2015. 
Tobón Marin, C., Bouten, W., and Sevink, J.: Gross rainfall and its partitioning into throughfall, stemflow and evaporation on intercepted water in four forest ecosystems in western Amazonia, J. Hydrol., 237, 40-57, 2000.

Wilkinson, P. L., Anderson, M. G., and Lloyd, D. M.: An integrated hydrological model for rain-induced landslide prediction, Earth Surf. Proc. Land., 27, 1285-1297, 2002.

Xiao, Q., McPherson, E. G., Ustin, S. L., Grismer, M. E., and Simpson, J. R.: Winter rainfall interception by two mature open-grown trees in Davis, California, Hydrol. Process., 14, 763-784, 2000.

Yamao, M., Sidle, R. C., Gomi, T., and Imaizumi, F.: Characteristics of landslides in unwelded pyroclastic flow deposits, southern Kyushu, Japan, Nat. Hazards Earth Syst. Sci., 16, 617-627, doi:10.5194/nhess-16-617-2016, 2016.

Zanchi, F. B., Waterloo, M. J., Tapia, A. P., Alvarado Barrientos, M. S., Bolson, M. A., Luizão, F. J., Manzi, A. O., and Dolman, A. J.: Water balance, nutrient and carbon export from a heath forest catchment in central Amazonia, Brazil, Hydrol. Process., 29, 3633-3648, 2015.

Zeng, N., Shuttleworth,. W., and Gash, J. H. C.: Influence of temporal variability of rainfall on interception loss. Part I. Point analysis, J. Hydrol., 228, 228-241, 2000.

Ziegler, A. D., Giambelluca, T. W., Tran, L. T., Vana, T. T., Nullet, M. A., Fox, J. M., Vien, T. D., Pinthong, J., Maxwell, J. F., and Evett, S.: Hydrological Consequences of Landscape Fragmentation in Mountainous Northern Vietnam: Evidence of Accelerated Overland Flow Generation, J. Hydrol., 287, 124-146, 2004.
Ziegler, A. D., Negishi, J. N., Sidle, R. C., Noguchi, S., and Abdul Rahim, N.: Impacts of logging disturbance on saturated hydraulic conductivity in a tropical forest in peninsular Malaysia, Catena, 67, 89-102, 2006.

Ziegler, A. D., Giambelluca, T. W., Nullet, M. A., Sutherland, R. A., Tantasarin, C., Vogler, J. B., and Negishi, J. N.: Throughfall in an evergreen-dominated forest stand in northern Thailand: Comparison of mobile and stationary methods, Agr. Forest Meteorol., 149, 373-384, 2009.

Ziegler, A. D., Sidle, R. C., Phang, V. X. H., and Wood, S. H.: Bedload transport in SE Asian streams - uncertainties and implications for reservoir management, Geomorphology, 227, 31-48, doi:10.1016/j.geomorph.2014.01.015, 2014a.

Ziegler, A. D., Benner, S. G., Tantasirin, C., Wood, S. H., Sutherland, R. A., Sidle, R. C, Jachowski, N. R. A., Lu, X., Snidvongs, A., Giambelluca, T. W., and Fox, J. M.: Turbiditybased sediment monitoring in northern Thailand: hysteresis, variability, and uncertainty, J. Hydrol., 519, 2020-2039, doi:10.1016/j.jhydrol.2014.09.010, 2014b.

Ziemer, R. R.: Roots and the stability of forested slopes, in: Erosion and Sediment Transport in Pacific Rim Steeplands, edited by: Davies, T. R. H. and Pearce, A. J., 343-361, IAHS, Christchurch, New Zealand, 1981. 